\title{
TRACING TRANSCONTINENTAL SAND TRANSPORT: FROM ANATOLIA-ZAGROS TO THE RUB' AL KHALI SAND SEA
}

\author{
EDUARDO GARZANTI $^{1 *}$, PIETER VERMEESCH ${ }^{2}$, KHALID ABDULSAMAD AL-RAMADAN $^{3}$, \\ SERGIO ANDÒ ${ }^{1}$, MARA LIMONTA ${ }^{1}$, MARTIN RITTNER $^{2}$, GIOVANNI VEZZOLI $^{1}$
}

${ }^{1}$ Laboratory for Provenance Studies, Department of Earth and Environmental Sciences, University of Milano-Bicocca, 20126 Milano, Italy

${ }^{2}$ London Geochronology Centre, Department of Earth Sciences, University College London, London, WC1E 6BT, UK

${ }^{3}$ King Fahd University of Petroleum \& Minerals, Dhahran, 31261 Saudi Arabia.

* Corresponding author. Tel.: +39-02-64482088; fax: +39-02-64482073

E-mail addresses: eduardo.garzanti@unimib.it (E. Garzanti),p.vermeesch@ucl.ac.uk (P.Vermeesch), ramadank@kfupm.edu.sa (K.A. Al-Ramadan), sergio.ando@unimib.it (S. Andò), mara.limonta@unimib.it (M.Limonta),m.rittner@ucl.ac.uk (M.Rittner), giovanni.vezzoli@unimib.it (G. Vezzoli),

${ }^{1}$ Tel.: +39-02-64482088; fax: +39-02-64482073

${ }^{2}$ Tel.: +44-020-76792418; fax: +44-020-76792867

${ }^{3}$ Tel: $+966-3-8607175$

KEY WORDS: Sand petrography; Heavy minerals; U-Pb zircon geochronology; Sediment dispersal pathways; Intrasample mineralogical variability; Mineral durability during eolian transport. 


\section{ABSTRACT}

1 We used petrographic, heavy-mineral and geochronological signatures of sand-sized grains to

2 document an exceptional case of long-distance sediment transport dominated by eolian processes in

3 hyperarid climate. Feldspatho-quartzo-lithic orogenic detritus shed by the Anatolia Plateau and

4 Zagros Mountains - including carbonate, chert, volcanic, metabasite and ultramafic lithic grains

5 with a rich epidote-amphibole-pyroxene-garnet heavy-mineral suite - was carried to the Arabian-

6 Gulf foreland basin via the Euphrates-Tigris-Karun fluvial system and other rivers draining the

7 Zagros, and blown inland by dominant Shamal winds to reach well into the Arabian foreland.

8 Sediment dispersal over a cumulative distance of up to $4000 \mathrm{~km}$ took place in multiple steps,

9 involving extensive eolian reworking of older deposits during lowstand stages of the Pleistocene

10 before final accumulation in the Rub' al Khali sand sea. The siliciclastic fraction of Gulf beaches

11 changes southeastwards from litho-quartzose carbonaticlastic and quartzose north of Qatar to

12 quartzo-lithic carbonaticlastic along the Trucial Coast, but invariably contains chert, volcanic and

13 metabasite lithics, together with epidote, pyroxene, amphibole, and garnet. Dune sand inland is

14 progressively enriched in quartz until composition becomes feldspatho-quartzose, whereas the

15 heavy-mineral assemblage remains virtually unchanged. Beach and dune sands of the Gulf and

16 northeastern Rub' al Khali were derived from Arabia, Anatolia and the Zagros in varying

17 proportions, with only local contribution from ophiolites of the northern Oman Mountains as

18 revealed by cellular serpentinite and enstatite grains. In all samples detrital zircons yielded mostly

19 Cambrian to Neoproterozoic ages reflecting "Pan-African" crustal growth and amalgamation of the

20 Arabian shield, but several Upper Paleozoic, Mesozoic, and Cenozoic zircons with ages as young as

$215 \mathrm{Ma}$ in northeastern Rub' al Khali dunes document ultimate provenance from the Anatolia-Zagros

22 orogen. Quartzose dune sand of the southwestern Rub' al Khali, containing a moderately poor,

23 amphibole-rich heavy-mineral assemblage and very few young zircons, is dominantly Arabian-

24 derived. Relatively soft carbonate grains are typically concentrated in finer sand classes, which is

25 ascribed to both mixing with coarser quartz recycled from Arabian siliciclastic covers and selective 
26 mechanical wear during multicyclic long-distance transport in high-energy eolian environments.

27 Understanding the complex transfer of huge detrital masses on the Earth's surface, and mixing of 28 sediments derived from different sources along successive tracts of a composite routing system that 29 may cover cumulative distances of thousands of kilometers across climatic and tectonic boundaries

30 over time periods of millions of years, is essential to enhance the resolution of source-to-sink 31 studies and avoid gross oversimplifications in paleogeographic reconstructions. 
"Realistic concepts about provenance relations require attention to the variability and complexity of sediment dispersal systems on a dynamic earth."

Dickinson 1988

"You have not awakened to wakefulness, but to a prior dream. This dream is enclosed within another, and so on to infinity, which is the number of grains of sand. The path you must retrace is interminable and you will die before you have truly awakened." Jorge Luis Borges, La escritura del dios, El Aleph, 1949

\section{INTRODUCTION}

A great challenge to provenance studies is posed by the variability of source-to sink dispersal paths, which may involve diverse configurations of fluvial, eolian, shallow-marine or deep-marine tracts, each extending over several hundreds or even thousands of kilometers in length (Dickinson 1988). A common case is that of coupled fluvial and turbiditic transport, in which sediment generated in high mountain ranges is carried by gravity-driven currents along a winding route to the coast and next across the continental shelf and slope to eventually reach the abyssal ocean floor (Zuffa et al. 2000; Ingersoll et al. 2003; Limonta et al. 2015). Less commonly documented is long-distance transport in littoral environments alongshore and onshore, where sand blown by dominant winds can climb up to a thousand meters uphill over a distance of hundreds of kilometers inland (Garzanti et al. 2012a, 2014).

The complexities of ultra-long sediment-routing systems can be unraveled in full detail only by the use of complementary provenance techniques in modern settings, where we can gain complete knowledge on the topography, areal extent, lithology and tectonic structure of source terranes, as well as on climatic conditions including atmospheric and oceanic circulation patterns. In this article we use petrographic, heavy-mineral and geochronological signatures of sand-sized grains to monitor sediment transfer along the southern coast of the Arabian Gulf, and beyond it toward the heart of the huge Rub' al Khali sand sea (Fig. 1). The present article is based on, and represents the continuation of two provenance studies on eolian and fluvial sands of northern Arabia and the Euphrates-Tigris-Karun rivers (Garzanti et al. 2013, 2016), which allowed us to determine 
accurately the composition of sediments derived and transported from both the Arabian foreland and the Anatolia-Zagros orogen to the Mesopotamian-Gulf foreland basin. We can thus document a remarkable case of multi-step sediment transfer over a distance of thousands of kilometers, characterized by repeated recycling throughout the Quaternary and dominated by eolian processes in hyperarid climatic conditions.

88

The Arabian plate is delimited by the Bitlis-Zagros convergent plate boundary in the north and north-east, and by the Levant-Red Sea-Gulf of Aden divergent plate boundary in the west and south. A central shield, generated during Neoproterozoic accretion of continental microplates and arc terranes (Johnson et al. 2011), tilted gently toward the Gulf, is overlain by a semicircular belt of eastward-younging Paleozoic to Cenozoic siliciclastic to shallow-marine carbonate strata (Fig. 2; Alsharhan and Nairn 1997; Cantrell et al. 2014).

Strong weathering and erosion followed the Neoproterozoic ("Pan-African") orogeny, when the region became a vast low-relief surface upon which Lower Paleozoic sandstones were deposited non-conformably (Avigad et al. 2005). The thick succession exposed on the Wajid Plateau south of the central shield, consisting of fluvio-glacial to shallow-marine conglomerates and quartzose sandstones with locally interbedded mudrocks, has been subdivided into several formations separated by unconformities and ranging in age from the Cambro-Ordovician to the early Permian (Al-Ajmi et al. 2015). Outcrops of Permian limestones and Triassic strata are limited in the area. The Jurassic succession exposed in Jabal Tuwaiq (jabal = mountain) consists of shallow-marine carbonates, intercalated with shales and sandstones at the base and capped by evaporites. A thick succession of Paleogene carbonates and evaporites overlying deltaic to shallow-marine quartzose 
sandstones of Cretaceous age is exposed in the Hadhramaut carbonate tableland sloping gently northward toward the Rub' al Khali. Weakly metamorphosed Neoproterozoic to Lower Paleozoic strata and overlying Tethyan carbonates of the Arabian platform crop out in the Huqf arch to the north-east, and within tectonic windows in the northern Oman Mountains farther north (Glennie et al. 1974). Mesozoic carbonates are also exposed in the Musandam Peninsula, representing the eastern termination of the Zagros thrust belt (Searle et al. 1983). The Sama'il Ophiolite, spectacularly exposed along an arcuate belt $\sim 500 \mathrm{~km}$ long in northern Oman, includes 8-12 kmthick serpentinized mantle harzburgites, 3-6 km-thick gabbros with ultramafic cumulates at the base and plagiogranite pockets at the top, $1-1.5 \mathrm{~km}$-thick diabase sheeted dikes, and $0.5-2 \mathrm{~km}$-thick pillow basalts overlain by thin metalliferous strata and radiolarites (Lippard et al. 1986). Tectonically imbricated beneath the ophiolite are Permo-Mesozoic radiolarian cherts and limestone turbidites well exposed along the southern front of the orogen (Hawasina thrust sheets; Béchennec et al. 1990).

Arabia lies within the trade-wind belt of the Northern Hemisphere. Winds travel from the Mediterranean Sea toward the Gulf, and next turn to the south and southwest toward the core of the Rub' al Khali (Fig. 3). Northwesterly winds blow in early winter and late spring. Maximum release of eolian energy is in June to early July, when Shamal (shamal = north) wind may last for weeks with speeds of $40-50 \mathrm{~km} / \mathrm{h}$ and gusts up to $100 \mathrm{~km} / \mathrm{h}$. Dust storms are generated during the day, whereas wind calms down at night. Sand is deflated in the higher-energy area north of Dammam and transported actively southward across the Jafurah Sand Sea (Fig. 1; Fryberger et al. 1984). Wind energy declines steadily southward and westward across the Rub' al Khali, where rare sandstorms occur (Vincent 2008 p.135-137). The southwesterly monsoon (mawsim = season), a humid summer wind bringing gusts up to $100 \mathrm{~km} / \mathrm{h}$ and rough seas along the coast of southeastern 
115 Arabia, blows in the opposite direction, with a branch swinging northward across the Wahiba Sands

116 toward the Oman Mountains (Glennie and Singhvi 2002).

117

118

119

120

121

122

123

124

125

126

127

128

129

130

131

132

133

134

135

136

137

138

139

140

\section{Dune fields}

The active dune fields of Arabia represent the largest continuous body of eolian sand on Earth (Fig. 2). Sand accumulates in the Great Nafud to the north and in the Rub' al Khali to the south, connected by sub-parallel arcuate corridors of mobile reddish dunes running from north to south along topographic depressions delimited by resistant strata (e.g. Jurassic limestone of Jabal Tuwaiq). The Nafud corridors (nafud $=$ sandy desert) run at elevations $\geq 700 \mathrm{~m}$ a.s.l. west of Jabal Tuwaiq, whereas the Ad Dahna corridor swings east of it in a $1200 \mathrm{~km}$-long by $30-80 \mathrm{~km}$-wide arc at elevations declining southward from 560 to $300 \mathrm{~m}$ a.s.1.. Mobile barchans of light brown sand characterize the Jafurah sand sea, starting north of Dammam and widening southward along the Gulf coast to finally merge into the Rub' al Khali.

The Rub' al Khali (or Empty Quarter, known locally as Ar Ramlah = The Sands) occupies the $\sim 600,000 \mathrm{~km}^{2}$ wide rim basin behind the rift shoulders of the Red Sea and Gulf of Aden, with slopes decreasing steadily from $\sim 1200 \mathrm{~m}$ a.s.1. to the Trucial Coast of the United Arab Emirates (UAE). Potential evaporation exceeds precipitation by factors of 10 to 30 , rainfall is $<60 \mathrm{~mm} / \mathrm{year}$, and summer temperatures $>50^{\circ} \mathrm{C}$. Linear dunes are up to $250 \mathrm{~km}$-long, $1.5 \mathrm{~km}$-wide, $200 \mathrm{~m}$-high, and spaced from 2 to $6 \mathrm{~km}$ apart; star dunes are up to $300 \mathrm{~m}$-high (Vincent $2008 \mathrm{p} .138-144$ ). Compound mega-barchans up to 160 m-high migrate slowly landward at its upwind northeasternmost edge at Liwa (Goudie et al. 2000; Stokes and Bray 2005; Bishop 2013; Farrant et al. 2015). Seif dunes extend toward Oman with WNW-ESE-trending axes, whereas a branch is deflected northward along the front of the northern Oman mountains towards the Musandam Peninsula. In eastern Oman lie the coastal Wahiba Sands, where northward sand transport took place mostly during Pleistocene eustatic lowstands (Radies et al. 2004). The Rub' al Khali is 
141 delimited to the south by the Hadhramaut-Dhofar Arch, surrounded by locally fed dune fields (e.g.,

142 Ramlat as Sab'atayn in Yemen; Garzanti et al. 2001).

143

144

145

146

147

148

149

150

151

152

153

154

155

156

157

158

159

160

161

162

163

164

165

\section{The Gulf}

The Arabian (Persian) Gulf is the distal underfilled part of the Zagros foreland basin (Evans 2011).

Given the dry hot climate of the region, carbonate sedimentation flourishes along the Arabian coast, fringed by coral reefs, tidal flats, barrier islands and lagoons, ooidal shoals, beaches and sibakh $($ sabkhah $=$ flat dry salt-encrusted zone; Kendall and Alsharhan 2011). Carbonaticlastic terrigenous detritus derived from the Shatt al Arab estuary and from the Zagros Mountains along the opposite side, is however also significant (Baltzer and Purser 1990; Walkden and Williams 1998).

From Kuwait to Qatar, offshore winds supply quartzose sand that mixes and intercalates with shallow-marine carbonates (Fryberger et al. 1983) Coastal features are structurally controlled, with cuspate spits forming on structural highs whereas intervening embayments are infilled by beachridge and sabkha sediments (Lomando 1999). The Trucial (Pirate) Coast of the UAE receives no runoff from interior Arabia and most of the Oman Mountains. Water depths offshore are $<20 \mathrm{~m}$ and numerous islands lie atop salt domes and the Great Pearl Bank, the eolianite-cored peripheral bulge joining the coast at low angle north of Abu Dhabi (Farrant et al. 2012). Skeletal sands, including red algae from adjacent reefs, are deposited on high-energy shorelines, replaced by pellets and compound grains in sheltered areas. Tidal range of 1-2 $\mathrm{m}$ and current velocities up to $65 \mathrm{~cm} / \mathrm{s}$ within tidal channels favour development of oolitic ebb-tide deltas. Ooids form in open tidal flats and lagoons, where salinity reaches $50-70 \%$. Storm beaches backed by coastal dunes and several spits indicating northeastward longshore transport characterize the linear eastern coast, which is exposed obliquely to Shamal winds in the direction of the longest fetch (Purser 1973; Kendall and Alsharhan 2011). 
166 The Gulf was largely emergent during a significant part of the Quaternary. Its notably flat floor,

167 exposed extensively whenever sea-level fell below $-70 \mathrm{~m}$ during glacial periods, was entirely

168 subaerial during the Late Glacial Maximum when sea level dropped to -120 m (Glennie 1998). The

169 Tigris-Euphrates paleoriver then extended across lake-dotted marshlands all the way to the Straits

170 of Hormuz, where its entrenched channel debouched directly into the Gulf of Oman (Uchupi et al.

171 1999). The potential for wind deflation by northwesterly Shamal winds would have been greatest

172 during early regressive stages, when the unconsolidated sediments newly exposed by the receding

173 sea were not yet stabilised by vegetative cover or early cementation (Alsharhan and Kendall 2003).

174 Sea level returned to rise after the Late Glacial Maximum, when marine waters transgressed back

175 through the Straits of Hormuz, progressively drowning the lower reaches of the extended Tigris-

176 Euphrates paleoriver and thus permanently eliminating floodplain sediments as a source of eolian

177 sand (Lambeck 1996).

178 Relict Pleistocene paleodunes are exposed widely along the Gulf coast and in deflated areas as far

179 as $80 \mathrm{~km}$ inland (Williams and Walkden 2002). Moderately to well cemented, polyphase carbonate-

180 rich eolianites are underlain by siliciclastic paleodunes, resting disconformably in turn on the Upper

181 Miocene Baynunah Formation (Glennie and Singhvi 2002; Farrant et al. 2015). Baynunah

182 sediments rich in vertebrate fossils were deposited by a large fluvial system flowing constantly from

183 the west-north-west, possibly the Tigris-Euphrates paleoriver (Friend 1999; Hill et al. 2012). A

184 major drainage system also existed in central Arabia at wetter times, including an ancestral Wadi

185 Sahba, possibly joined by Wadi Dawasir (Al-Saad et al. 2002; fig. 6.5 in Edgell 2006; Bibi et al. 186 2013).

\section{METHODS}

190 During the field campaigns organized in Saudi Arabia by the King Fahd University in October 2014 191 and May 2016, we have collected 7 beach and 1 dune sands along the Gulf coast from Kuwait to 
192 Dammam, 19 dune sands in the northeastern Rub' al Khali along a NW-SE transect from west of

193 Sabkha Matti to Shaybah, Ardah and the Oman border, and 12 dunes and 2 sand sheets in the

194 southwestern Rub' al Khali (Fig. 1). For consistency and to avoid anomalous concentrations of 195 denser minerals due to wind turbulence along the flanks and stoss side of dunes, all samples were

196 taken from the crest at the top of the largest dune in each site. We also collected 1 gravel sample

197 from the alluvial fan-apron fed from the northern Oman Mountains, 10 sands on the bed of major 198 widyan (wadi = "dry valley") feeding into the southwestern Rub' al Khali, and one bedrock sample

199 from the Paleozoic Wajid Sandstone. These 52 samples integrate those studied in previous years, 200 covering fluvial systems of Mesopotamia, beaches along the southern coast of the Gulf, and rivers 201 and dune fields of northern Arabia, Oman and Yemen (Garzanti et al. 2001, 2003, 2013, 2016). Full 202 information on sampling sites is provided in Appendix Table A1 and Google-Earth ${ }^{\mathrm{TM}}$ map 203 Arabia\&Gulf.kmz.

\section{Sand petrography and heavy minerals}

A quartered fraction of each sand sample was impregnated with Araldite, cut into a standard thin section stained with alizarine red to distinguish dolomite and calcite, and analysed by counting 400 points under the microscope (Gazzi-Dickinson method; Ingersoll et al. 1984; Zuffa 1985). Wadi samples were gently washed to remove mud or wet sieved to obtain the $63-2000 \mu \mathrm{m}$ class if poorly sorted and containing granules. Sand classification is based on the main components quartz, 212 feldspars and lithic fragments considered if exceeding 10\%QFL (e.g., a sand is named litho213 feldspatho-quartzose if $\mathrm{Q}>\mathrm{F}>\mathrm{L}>10 \% \mathrm{QFL}$; Garzanti 2016). Metamorphic rock fragments were

214 subdivided into very low to low-rank metasedimentary or metavolcanic, and medium to high-rank 215 felsic or mafic categories (Garzanti and Vezzoli 2003). Criteria for distinguishing the intrabasinal 216 versus extrabasinal origin of calcareous and other grains are after Zuffa (1985) and Garzanti (1991). 217 Median grain size was determined in thin section by ranking sand samples from coarsest to finest 
218 followed by visual comparison with in-house standards sieved at 0.25 sieve interval.

219 Heavy-mineral analyses were carried out in bulk for well sorted dune samples, and on the $<500 \mu \mathrm{m}$,

$220 \quad 15-500 \mu \mathrm{m}$ or $32-500 \mu \mathrm{m}$ fraction obtained by wet sieving for less sorted wadi, beach, and sand221 sheet samples. Heavy minerals were separated by centrifuging in Na polytungstate (density $\sim 2.90$ $222 \mathrm{~g} / \mathrm{cm}^{3}$ ), recovered after partial freezing of the test tube with liquid nitrogen. The obtained fraction 223 was weighted, micro-quartered, and mounted on a glass slide with Canada balsam for counting. In 224 order to obtain real volume percentages, about 200 transparent heavy minerals were point-counted 225 under the microscope at a regular spacing wide enough to avoid counting the same grain twice 226 (Galehouse 1971). Altered and dubiously identified grains were checked by Raman spectroscopy 227 (Andò and Garzanti 2014). Heavy-mineral concentration, calculated as the volume percentage of 228 total (HMC) and transparent (tHMC) heavy minerals (Garzanti and Andò 2007), ranges from 229 extremely poor $(\mathrm{HMC}<0.1)$ and poor $(0.5 \leq \mathrm{HMC}<1)$ to rich $(5 \leq \mathrm{HMC}<10)$ and very rich $(10 \leq$ 230 HMC < 20). The ZTR index (sum of zircon, tourmaline and rutile over total transparent heavy 231 minerals; Hubert 1962) expresses the "mineralogical durability" of the suite (Garzanti 2017). 232 Detrital components are listed in order of abundance throughout the text. Key parameters are shown 233 in Table 1; the complete petrographic and heavy-mineral datasets are provided in Appendix Tables 234 A2 and A3.

\section{Detrital geochronology}

Detrital zircons were identified by QEMScan electron microscopy (Vermeesch et al. 2017) on the heavy-mineral separates of 27 selected sand samples from Saudi Arabia (32-500 $\mu \mathrm{m}$ class for wadi and beach sands, bulk sample for well sorted dune sands). U-Pb zircon ages were determined at the London Geochronology Centre using an Agilent 7700x LA-ICP-MS system, employing a NewWave 
244 middle of zircon grains. We deliberately decided not to image the grains, because this may introduce 245 bias. One of the advantages of the QEMScan is that all zircons are picked, including murky grains 246 easily discarded by visual inspection but invariably confirmed to be zircon by LA-ICP-MS analysis. 247 Data reduction was performed using GLITTER 4.4.2 software (Griffin et al. 2008). We used $248{ }^{206} \mathrm{~Pb} /{ }^{238} \mathrm{U}$ and ${ }^{207} \mathrm{~Pb} /{ }^{206} \mathrm{~Pb}$ ages for zircons younger and older than $1100 \mathrm{Ma}$, respectively. No 249 common $\mathrm{Pb}$ correction was applied (for further methodological information see supplementary 250 material in Rittner et al. 2016). Grains with $>+5 /-15 \%$ age discordance were discarded, and 2812 251 concordant ages were obtained overall (> 100 ages on 17/27 samples). Statistical techniques used for 252 data presentation include kernel density estimation (Vermeesch 2012) and multidimensional scaling, 253 which produces "maps" in which samples are arranged according to their statistical distance 254 (Vermeesch 2013). The full geochronological dataset is provided in Appendix B.

\section{DETRITAL SIGNATURES}

In this section we illustrate sand composition in beaches along the Arabian coast of the Gulf and in dune fields inland (Fig. 4 and 5). Descriptions are integrated with data on wadi sands and on beach and dune sands collected in previous years (Table 1).

\section{Beaches of the Arabian Gulf}

Along the Gulf coast, terrigenous siliciclastic and subordinately carbonaticlastic detritus mixes in various proportions with a locally overwhelming allochemical (coeval) to extrasequential (noncoeval) intrabasinal fraction represented by ooids with subordinate bioclasts (pelecypods, 
270 Beach sand from Kuwait to Qatar ranges from feldspatho-litho-quartzose to quartzose (Fig. 4A). 271 North of Dammam, feldspatho-litho-quartzose to litho-quartzose carbonaticlastic sand has 272 plagioclase/total feldspar ratio $(\mathrm{P} / \mathrm{F})$ up to 0.68 , more common volcanic, chert and metabasite 273 lithics, and very poor to poor heavy-mineral suite with ZTR $<10$, abundant epidote, common 274 clinopyroxene, garnet and amphibole, and minor hypersthene, Cr-spinel, titanite, staurolite and 275 enstatite. South of Dammam, feldspatho-quartzose to quartzose sand has $\mathrm{P} / \mathrm{F} \leq 0.25$ and extremely 276 poor to very poor suite with ZTR commonly reaching $\sim 30$.

277 Along the Trucial Coast of the UAE, beach sand is quartzo-lithic carbonaticlastic with $\mathrm{P} / \mathrm{F}$ $2780.60 \pm 0.15$ and common chert, mainly mafic volcanic, metabasite and siltstone/metasiltstones grains.

279 The mainly poor heavy-mineral suite includes abundant epidote associated with amphibole, garnet 280 and clinopyroxene, low ZTR (3 \pm 2$)$, and minor Cr-spinel. Cellular serpentinite grains and enstatite 281 are more common close to the Oman Mountains in the south-east.

\section{Coastal dune fields}

In Saudi Arabia, sparse dunes north of Dammam - where winds are stronger and deflation prevails (Fryberger et al. 1984) - are quartzose with minor feldspars (P/F 0.41), mainly carbonate rock fragments, and a poor epidote-amphibole-clinopyroxene-garnet heavy-mineral suite (ZTR 5). 288 Coastal Jafurah dunes south of Dammam are litho-feldspatho-quartzose (P/F $0.31 \pm 0.13$ ) with poor 289 to moderately poor epidote-clinopyroxene-amphibole-garnet suites (ZTR $8 \pm 3$ ). Dunes in Niqyan 290 Qatar and just south of the Qatar border are feldspatho-litho-quartzose (P/F 0.51 \pm 0.03 ), with 291 moderately poor clinopyroxene-amphibole-garnet-epidote or extremely poor epidote-dominated 292 suites (ZTR 5 \pm 2 ). Carbonate and subordinate volcanic, low-rank metasedimentary, metabasite and 293 chert lithics are concentrated in the fine tail of the size distribution (fig.7 in Garzanti et al. 2013). 294 Jafurah dunes inland are instead quartzose, with low $\mathrm{P} / \mathrm{F}(0.17 \pm 0.05)$ and very poor amphibole295 epidote-clinopyroxene-garnet suites with high ZTR (14 \pm 9$)$. 
296 Dune sand composition varies more markedly landward in the UAE (Pugh 1997; Hadley et al. 297 1998; Teller et al. 2000), where quartzo-lithic carbonaticlastic sand of creamy yellow coastal dunes 298 passes inland to feldspatho-litho-quartzose and eventually litho-feldspatho-quartzose sand of 299 reddish barchanoid megadunes in the Liwa oasis. Feldspars increase landward slower than quartz, 300 with rather constant $\mathrm{P} / \mathrm{F}(0.48 \pm 0.11)$. Chert grains are more common than volcanic and metabasite 301 grains. Serpentinite grains increase notably toward the Oman Mountains. Poor heavy-mineral suites 302 include mainly epidote associated with amphibole, garnet, and minor clinopyroxene and enstatite; 303 ZTR increases inland from 1 to 5-10.

304 305 306 307 308

\section{The northeastern Rub' al Khali}

Dune sands inland of Sabkha Matti are feldspatho-litho-quartzose to feldspatho-quartzo-lithic carbonaticlastic (Fig. 4B; P/F $0.54 \pm 0.06$ ) with a varied lithic population and poor to moderately poor epidote-amphibole-clinopyroxene-garnet heavy-mineral suites (ZTR 5 \pm 2 ). Megadunes in the Shaybah area are feldspatho-quartzose (Fig. 4C; P/F $0.55 \pm 0.06$ ), with a very poor to poor epidoteamphibole-garnet-clinopyroxene suite (ZTR 6 \pm 4 ). Dunes in the Ardah area are similarly feldspathoquartzose (Fig. 4F; P/F 0.48 \pm 0.12 ) with mainly very poor epidote-amphibole-garnet-clinopyroxene suites (ZTR 7 \pm 2 ), but may contain common carbonate grains concentrated in the fine tail of the size distribution (Fig. 4E). Anomalous concentration of ultrandense opaque Fe-Ti-Cr oxides and zircon (HMC up to 14) is induced locally by wind deflation on dune flanks.

\section{The southwestern Rub' al Khali}

Sand sheets and dunes along the western edge of the Rub' al Khali range from feldspatho-quartzose to quartzose (P/F 0.52 \pm 0.13$)$. Limestone grains may be concentrated in the fine tail of the size distribution together with a few siltstone/metasiltstone, metabasite, felsic metamorphic, volcanic/metavolcanic, dolostone, chert, and shale/slate grains. Heavy-mineral suites are 
323 moderately rich in sand sheet and dune sands at the northern and western edges of the desert, and

324 become mainly poor eastward into the sand sea (McClure 1984 p.102). Amphibole dominates over

325 epidote; zircon, garnet and clinopyroxene are minor, and staurolite, enstatite and hypersthene rare 326 (ZTR 7 \pm 4$)$.

\section{Arabian widyan}

330 Because of arid to hyperarid climate all Arabian rivers are ephemeral (widyan = dry valleys).

331 During more humid Pleistocene stages, however, major rivers now clogged by eolian sand were 332 capable of flowing to the Gulf (Edgell 2006). One was the Wadi Rimah-Wadi al Batin system, 333 which in rushing floods carried rock debris eroded from crystalline uplands of the Arabian shield, 334 cut steep-walled canyons through limestone plateaus, and finally spread out and dropped its load to 335 form a large alluvial fan, now the gently sloping Dibdiba deflated gravel plain between southern 336 Iraq and Kuwait (Holm 1960; Al-Sulaimi and Pitty 1995). Sand in Wadi Rimah and Wadi al Batin 337 is quartzose. The very poor heavy-mineral suite consists of a largely eolian coarser fraction rich in 338 zircon, tourmaline and rutile, with a fluvial finer fraction rich in amphibole and clinopyroxene (ZTR 339 41-42), indicating extensive mixing with eolian sand across Nafud and Dahna dune corridors.

340 In central Arabia, Wadi Sahba drains the Tuwaiq limestone plateau and once ran eastward to Harad 341 (Anton 1983), from where a series of divergent gravel trains fan out toward Sabkha Matti (fig. 6.6 342 in Edgell 2006). Sand in Wadi Sahba and in other streams also draining Jabal Tuwaiq (Wadi 343 Ushayrab, Maqran, and Sulayyil) is quartzo-lithic carbonaticlastic with a very poor amphibole-rich 344 heavy-mineral suite including common epidote, and minor zircon, clinopyroxene, tourmaline and 345 rutile (Fig. 5A; ZTR 16 \pm 9 ).

346 Wadi ad Dawasir once deposited a broad gravel plain now largely covered by Rub' al Khali dunes.

347 Fine sand is litho-quartzose carbonaticlastic whereas medium sand is feldspatho-litho-quartzose $348(\mathrm{P} / \mathrm{F}$ 0.65 \pm 0.12$)$, revealing mixed provenance from the Arabian shield and its Paleozoic to Jurassic 
cover strata (Fig. 5B). The moderately poor, hornblende-dominated suite includes common epidote, and minor zircon and clinopyroxene (ZTR 4 \pm 1$)$.

In southwestern Arabia, Wadi Hubuna and Wadi Qatan drain the Arabian shield and carry feldspatho-quartzose metamorphiclastic/plutoniclastic sand (Fig. 5C; P/F 0.68 \pm 0.25 ) with a moderately rich to very rich hornblende-epidote suite including clinopyroxene and minor garnet and hypersthene (ZTR 2 \pm 2 ). Wadi Hima and Wadi Najran, draining exclusively and in part Paleozoic sandstones respectively, carry virtually purely quartzose and quartzose sand with very poor and moderately poor amphibole-dominated suites including epidote, clinopyroxene, garnet, hypersthene, and locally olivine (Fig. 5D; ZTR 3 \pm 1 ). The Paleozoic Wajid Sandstone is quartzose with a few feldspars (Fig. 5E; P/F 0.63) and an extremely poor heavy-mineral suite with high ZTR (54) including a few garnet, staurolite and amphibole grains.

\section{Omani and UAE widyan}

Wadi Kabir and Wadi Sumaini draining the southwestern flank of the northern Oman mountains carry lithic ultramaficlastic sand with rich to very rich enstatite-olivine or epidote-amphiboleenstatite suites also including clinopyroxene and hypersthene. Wadi Ghub and Wadi Dhaid in the eastern UAE carry quartzo-lithic sedimentaclastic sand with moderately rich to very rich epidoteclinopyroxene-amphibole suites including enstatite, garnet, hypersthene, olivine, and Cr-spinel. Wadi Bih draining the Musandam peninsula carries almost purely carbonaticlastic lithic sand.

Intrasample compositional variability is primarily a settling-equivalence effect (Rubey 1933), dense and ultradense detrital components being progressively and systematically enriched in finer classes of the size distribution (Fig. 6; see Garzanti et al. 2008 for detailed quantification of size-density 
375

376

377

378

379

380

381

382

383

384

385

386

387

sorting effects). Exceptions to the rule may reveal mixing of detrital populations with different provenance and grain size, providing key information for a refined textural interpretation and provenance analysis (e.g., Garzanti et al. 2015).

\section{Framework petrography}

For ten dune samples, five each for the northeastern and southwestern Rub' al Khali, data were obtained by point-counting in thin section by using separate sheets for grains of fine, medium, and coarse sand size measured by an ocular micrometer applied to the microscope (Fig. 6A,B). In lightcream dunes inland of Sabkha Matti, plagioclase prevails over K-feldspar with $\mathrm{P} / \mathrm{F}$ ratio decreasing markedly with grain size. Abundant limestone and dolostone grains are associated with chert, metasedimentary, metavolcanic and volcanic lithics in the fine class, whereas the coarse class consists dominantly of mainly rounded quartz (Fig. 4B). Such a notable concentration of plagioclase and lithic grains in the fine class cannot be ascribed to either size-density sorting or selective abrasion, because these grains are as dense or only a little denser than quartz, and some (e.g., chert) are even more resistant than monocrystalline quartz to mechanical wear (Harrell and Blatt 1978; McBride and Picard 1987 p.1025). Provenance control is thus revealed.

In the Shaybah and Ardah areas, all lithic fragments decrease toward the heart of the Uruq al Mutaridah $($ uruq $=$ linear dunes) because of mixing in larger proportions with quartzose detritus derived from Arabian sources (Fig. 4). But carbonate grains decrease in abundance and size faster than tougher chert grains (Fig. 7), and are commonly observed to concentrate markedly in the fine tail of the size distribution just before they finally disappear downwind (Fig. 4B,E). Size reduction and roundability of carbonate grains by mechanical wear has been documented already a century ago (Wentworth 1919). Otherwise detrital modes do not show marked grain-size control, and feldspars tend to increase slightly in the coarse sand class, with rather constant $\mathrm{P} / \mathrm{F}$. 
400 In dunes and sand sheets of the southwestern Rub' al Khali, feldspars and lithic grains (carbonate 401 and subordinately metavolcanic, metasedimentary, chert, siltstone, metabasite) are markedly 402 concentrated in the fine class, where K-feldspar and plagioclase are equally abundant $(\mathrm{P} / \mathrm{F}$ $4030.45 \pm 0.05)$. Quartz increases in coarser classes, where K-feldspar prevails (P/F 0.28 \pm 0.11$)$. Mixing 404 of quartz-rich sand recycled from mostly Paleozoic quartzose sandstones with finer detritus derived 405 from the Arabian shield and Mesozoic sedimentary covers is indicated.

\section{Heavy minerals}

Intrasample variability was investigated in detail for the Taroot beach and the Tamani dune

411 for the Taroot beach, representing $81 \%$ of the bulk sample in weight and $98 \%$ of the total dense 412 fraction, and nine subclasses between 63 and $300 \mu \mathrm{m}$ for the Tamani dune, representing 95\% of the 413 bulk sample and $99.5 \%$ of the total dense fraction, were analysed separately (Fig. 6C).

414 In the Taroot sample, heavy-mineral and transparent-heavy-mineral concentrations decrease 415 systematically from 16 and 11 in the finest analysed subclass, where ultradense monazite was 416 recorded and zircon is most common, to 0.11 and 0.04 in the coarsest analysed subclass, where low417 density tourmaline and andalusite reach maximum. Not all minerals, however, conform to the 418 settling-equivalence principle. Relatively low-density pyroxene is most abundant in the finest 419 subclass, and together with garnet and amphibole reaches a relative minimum in the modal subclass, 420 where epidote, largely hosted within rock fragments, reaches maximum.

421 In the Tamani sample, the HMC and tHMC indices also decrease systematically from the finest (17 422 and 14$)$ to the coarsest analysed subclasses (0.13 and 0.03$)$. Ultradense minerals, however, do not 423 reach their relative maximum in the finest subclass but in the 106-125 $\mu \mathrm{m}$ (opaque $\mathrm{Fe}-\mathrm{Ti}-\mathrm{Cr}$ 424 oxides), 125-150 $\mu \mathrm{m}$ (zircon, rutile) or 150-180 $\mu \mathrm{m}$ (garnet) subclasses. Epidote, staurolite, and less 
425 regularly garnet unexpectedly increase progressively with grain size relative to lower-density 426 amphibole.

427 Anomalies in size-density relationships can be investigated by settling-equivalence analysis 428 (Garzanti et al. 2008), which indicates that the settling-equivalence principle accounts for no more 429 than a fifth and a third of intrasample variability in the Taroot and Tamani samples, respectively. In 430 both samples, size shifts (i.e., differences between the size of a given mineral and bulk-sample grain 431 size measured in units) do not increase progressively from less dense to ultradense heavy 432 minerals as theoretically predicted, and are similar or even higher for clinopyroxene than for zircon 433 (0.57 vs. 0.55 for Taroot beach, 0.42 vs. 0.35 for Tamani dune, respectively). This indicates 434 mixing of zircon-bearing and virtually pyroxene-free quartzose sand recycled from Arabian 435 siliciclastic covers with a nearly half- -class finer, pyroxene-bearing detrital population. In the 436 Taroot beach such a population is characterized by a distinct Mesopotamian (i.e., Tigris + 437 Euphrates) signature, whereas in the Tamani dune it is derived largely from the outer flank of the 438 Red Sea rift shoulder although possibly in minor part even ultimately long-distance from the 439 Anatolia-Zagros orogen. Most heavy-mineral species are mainly subrounded, which suggests that 440 the violation of the settling-equivalence principle is not caused by faster mechanical wear of 441 clinopyroxene relative to tougher zircon in eolian environments.

442 The anomalous marked decrease in the ratio between ferromagnesian minerals and denser epidote 443 with increasing grain size in the fine tail of the Taroot beach sample may reflect the finer size of 444 detritus rich in amphibole and pyroxene largely derived from Anatolia via the Euphrates and Tigris 445 Rivers than the less travelled epidote-rich detritus derived from the Zagros thrust belt exposed along 446 the opposite side of the Gulf. The even more notably anomalous decrease in the amphibole/epidote 447 ratio with grain size observed in the Tamani dune sample suggests mixing of amphibole-rich 448 detritus carried by local widyan draining the Arabian shield with notably coarser detritus recycled 449 from largely Paleozoic siliciclastic covers also supplying zircon, garnet, and staurolite. 
453 The markedly bimodal composition displayed by many coastal Jafurah (fig. 7 in Garzanti et al. 454 2013) and northeastern Rub' al Khali dunes (Fig. 4B,E) is largely ascribed to mixing of detrital 455 populations with different provenance and grain size. Namely, the generally predominant coarser456 grained sand derived from anorogenic Arabian covers, chiefly consisting of recycled 457 monocrystalline quartz and a few feldspars (mainly K-feldspar), mixes with a subordinate to minor 458 finer-grained lithic-rich population of orogenic provenance derived from Anatolia and the Zagros 459 Mountains.

460 Other factors however, contribute to such notable intrasample compositional variability, including 461 not only hydraulic sorting but also different resistance of different detrital minerals to mechanical 462 abrasion. Greater toughness of chert relative to limestone grains (McBride and Picard 1987; Picard and McBride 2007) explains why the former - which are mainly subangular whereas the latter are almost invariably rounded to well rounded - increase relative to total sedimentary and metasedimentary lithics from $8 \pm 5 \%$ in the fine sand class to $28 \pm 12 \%$ in the medium sand class of 466 dunes inland of Sabkha Matti (Fig. 7). Beside extensive recycling of rounded quartz grains (Fig. 467 5E), innumerable strong impacts in the eolian environment may represent an additional factor contributing to the dominance of rounded quartz in the coarse sand class (e.g., Fig. 4B). In southwestern Rub' al Khali dunes, the very small size of limestone grains (Fig. 5F) would indicate very limited resistance to mechanical wear if derived largely from nearby sources (e.g., Jabal 471 Tuwaiq, Hadhramaut Arch), and may thus suggest long-distance transport all across the vast sand 472 sea. 
476 In all 27 sand samples from Saudi Arabia detrital zircons yielded mostly Cambrian to 477 Neoproterozoic ages $(85 \pm 7 \%$ between 490 and $1100 \mathrm{Ma})$, reflecting crustal growth and 478 amalgamation of the Arabian shield during the polyphase "Pan-African" orogenic events (Avigad et 479 al. 2003; Johnson et al. 2011; Morag et al. 2011). Within such a broad, major "Pan-African" age 480 cluster, $\mathrm{U}-\mathrm{Pb}$ spectra show a major peak centered at $624 \mathrm{Ma}$, and subordinate ones at 750-820 Ma 481 and 920-1030 Ma. Mid-Paleoproterozoic (1.74-2.15 Ga) and earliest Paleoproterozoic-Neoarchean 482 clusters $(2.40-2.73 \mathrm{Ga})$ occur in all samples but each represents $<5 \%$ of total grains in most. All 483 detrital zircons are older than $350 \mathrm{Ma}$ in sands of Wadi Dawasir, Hima, Hubuna and Najran, 484 draining the Arabian shield and/or its Paleozoic covers, whereas minor populations of young 485 zircons characterize Gulf beaches, Jafurah, and Rub' al Khali dunes (Fig. 8).

486 Grains with Miocene to Cretaceous ages represent between $1.8 \%$ and $3.7 \%$ of analysed zircons in 487 Gulf beaches (five ages from 5 to $47 \mathrm{Ma}$ and two at 70 and $96 \mathrm{Ma}$ ) and in eastern Jafurah (four 488 from 26 to $46 \mathrm{Ma}$, seven from 74 to $113 \mathrm{Ma}$ ), inland Sabkha Matti (three from 34 to $50 \mathrm{Ma}$, seven 489 from 71 to $100 \mathrm{Ma}$ ), Shaybah (six from 5 to $41 \mathrm{Ma}$, seven from 71 to $110 \mathrm{Ma}$ ), and Ardah dunes 490 (two at 30 and $41 \mathrm{Ma}$, five from 77 to $99 \mathrm{Ma}$ ). Late-Middle Jurassic to Permian-Carboniferous 491 zircons also occur, and form clusters in dunes inland of Sabkha Matti (five ages from 153 to 174 492 Ma, twelve from 260 to $333 \mathrm{Ma}$ ). Young grains are much rarer in southwestern Rub' al Khali dunes 493 and sand sheets, where a few Devonian-Silurian ages were obtained but only four out of 1063 dated 494 zircons yielded Cenozoic (47 Ma in the Sharurah dune), Mesozoic (98 and $244 \mathrm{Ma}$ ) or Upper 495 Carboniferous ages (315 Ma). SAND PROVENANCE FROM THE GULF TO THE NORTHEASTERN RUB' AL KHALI

Along the Arabian coast of the Gulf, intrabasinal allochems and extrasequential grains recycled 500 from Pleistocene eolianites and underlying Miocene strata are mixed in various proportions with 501 four different populations of extrabasinal terrigenous detritus (Fig. 10): 1) a quartzose population 
502 with a very poor heavy-mineral suite relatively rich in zircon, tourmaline and rutile ultimately 503 derived from interior Arabia; 2) a feldspatho-quartzo-lithic population with a rich amphibole504 pyroxene-epidote-garnet suite derived long-distance from Anatolia and the northern Zagros 505 Mountains via the Euphrates and Tigris rivers; 3) a lithic carbonaticlastic population with a poor 506 heavy-mineral suite relatively rich in epidote derived from the southern Zagros Mountains; 4) a 507 lithic cherticlastic-carbonaticlastic to ultramaficlastic population with an up to very rich heavy508 mineral suite characterized by enstatite derived from the Oman Mountains (Ahmed et al. 1998; 509 Walkden and Williams 1998; El-Sayed 1999, 2000; Nasir et al. 1999). The detrital signatures of 510 these four populations are defined in detail based on data also from Garzanti et al. (2002, 2003, $5112013,2016)$.

512 The mixing proportions of such four different detrital populations were quantified by forward 513 mixing models based on integrated bulk-petrography and heavy-mineral data (Garzanti et al. 2012b; 514 mathematical approach illustrated in Appendix A). Because we could not collect dune sand in the 515 central part of the erg, two separate sets of calculations were performed for Gulf and northeastern 516 Rub' al Khali sands (discussed in this section) and southwestern Rub' al Khali sands (presented in 517 the next section below). For Gulf beaches and northeastern Rub' al Khali dunes, the four end518 members were defined as the average composition of sands in: 1) Dahna dunes and Wadi Rimah-al 519 Batin; 2) Euphrates and Tigris Rivers including sediments of the Mesopotamian floodplain; 3) 520 Karun River and Shatt al Arab; 4) Oman pediment and widyan draining the southern flank of the 521 northern Oman mountains. For southwestern Rub' al Khali dunes and sand sheets, three different 522 Arabian end-members were defined as the average composition of sands in: 1a) Wadi Qatan and 523 Wadi Hubuna for Arabian basement; 1b) Wadi Hima and Wajid sandstone for siliciclastic Paleozoic 524 covers; 1c) Wadi Ushayrab and Wadi Maqran for mostly carbonate Mesozoic covers. Because 525 recycling of Quaternary eolianites and underlying Miocene sandstones (Farrant et al. 2012) could 526 not be quantified, all grains were considered as derived ultimately from source rocks. The effect of 527 mechanical wear was neglected for the sake of simplicity, and contribution from carbonate-rich 
528

529

530

531

532

533

534

535

536

537

538

539

540

541

542

543

544

545

546

547

548

549

550

551

552

sources (e.g., Zagros fold-belt) may have thus been underestimated. Because of a far more accurate definition of Anatolia and Zagros end members, the estimates presented here are considered as better constrained than those obtained previously (Garzanti et al. 2003, 2013).

\section{The recycled Arabian component}

Because of scarce rainfall and modest relief, erosion rates and sediment yields are very low in the heart of the Arabian shield exposed along the gently tilted eastern flank of the Red Sea rift shoulder. As a consequence of low transport capacity, fluvial contribution to the sand seas is minor, as displayed by contrasting composition of wadi sand and adjacent eolian dunes at the edge of the ergs (figs. 5 and 6 in Garzanti et al. 2013). As soon as they leave the shield, even major widyan are rapidly choked by eolian sands largely generated by local disaggregation of siliciclastic cover strata. Extensive recycling of Paleozoic and subordinately Mesozoic units is indicated for the Great Nafud and Dahna dune fields of northern Arabia, containing virtually pure quartz sand with very poor heavy-mineral suites characterized by zircon, tourmaline and rutile (quartz $98 \pm 2 \%$ of bulk sediment, ZTR 45 \pm 11 ; Garzanti et al. 2013). Such a highly quartzose composition is never reached

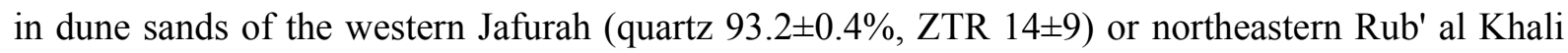
dune fields (quartz $78 \pm 12 \%$, ZTR $6 \pm 2$ ), reflecting progressive mixing with low-quartz, low-ZTR orogenic detritus eastwards. Cambrian to Neoproterozoic U-Pb zircon ages are dominant in all of the studied samples, indicating that the majority of zircon grains in all Arabian dune fields as well as in beaches of the Gulf are ultimately derived from the Arabian basement assembled during multiphase "Pan African" orogenic events. 
553 Steady northward compositional changes of dune sand from the Uruq al Mutaridah to the Liwa

554 oasis and the Trucial coast document mixing in increasing proportions with orogenic detritus 555 derived long-distance from the Anatolia-Zagros orogen (figs. 4 and 8 in Garzanti et al. 2013). 556 Orogenic contribution, documented by chert, volcanic, carbonate, low-rank metabasite and 557 ultramafic grains, is estimated to increase progressively from $18 \pm 3 \%$ for feldspatho-quartzose sand 558 in Ardah dunes, to $24 \pm 7 \%$ for feldspatho-quartzose sand in Shaybah dunes, $36 \pm 4 \%$ for litho559 feldspatho-quartzose sand in Liwa dunes, $59 \pm 19 \%$ and $59 \pm 7 \%$ for feldspatho-litho-quartzose dune 560 sand respectively inland of Sabkha Matti and in the intermediate belt of the UAE, and to $87 \pm 5 \%$ 561 and $94 \pm 5 \%$ for quartzo-lithic sand respectively in dunes and beaches of the Trucial coast. The 562 carbonaticlastic Zagros component, dominant in beaches and dunes of the Trucial coast, fades 563 rapidly inland also partly because of selective mechanical wear of soft carbonate grains, and it is 564 minor relative to the Mesopotamian (Tigris + Euphrates) component from the Liwa oasis to the 565 Uruq al Mutaridah. Orogenic detritus, with prevalence of Mesopotamian over Zagros contribution, 566 is estimated to increase eastward from $5 \pm 1 \%$ in quartzose sand of western Jafurah dunes to $35 \pm 10 \%$ 567 in feldspatho-litho-quartzose to litho-fedlspatho-quartzose sand of coastal Jafurah and Niqyan Qatar 568 dunes, and northward from only $4 \pm 3 \%$ in quartzose sand of Gulf beaches between Qatar and 569 Dammam to $28 \pm 18 \%$ in quartzose to feldspatho-litho-quartzose sand between Dammam and 570 Kuwait.

571 Because post-Devonian detrital zircons are absent in wadi sands derived from the Arabian shield 572 and its siliciclastic cover units (Garzanti et al. 2013), young grains need to come from elsewhere. 573 Miocene to Carboniferous zircons represent about a quarter of grains carried by the Euphrates 574 (19\%), Tigris (27\%) and Karun Rivers (29\%; Garzanti et al. 2016). Euphrates age-spectra are 575 characterized by small Miocene-Oligocene (15-34 Ma) and Late Cretaceous clusters (77-98 Ma) 576 with few Permian-Devonian grains, whereas Tigris spectra include small Eocene (33-57 Ma), mid577 Late Cretaceous, (72-115 Ma), Middle Jurassic (167-169 Ma), Late Triassic (225-230 Ma) and 578 Permian-Carboniferous clusters (285-338 Ma) with few Devonian-Silurian grains. The Karun 
579

580

581

582

583

584

585

586

587

588

589

590

591

592

593

594

595

596

597

598

599

600

601

602

603

604

carries to the Shatt al Arab a few zircons as young as 6-8 Ma and a continuum of Paleogene to Silurian zircons forming a major Jurassic (155-180 Ma) and a secondary Permian-Carboniferous cluster (290-315 Ma). Age clusters in the Euphrates-Tigris-Karun river system match well and thus explain the occurrence of small but significant Miocene-Eocene and mid-Late Cretaceous populations found in Gulf beaches and northeastern Rub' al Khali dunes (Fig. 8). Ages as young as latest Miocene in one beach and one dune sample, and Late-Middle Jurassic and PermianCarboniferous clusters in dunes inland of Sabkha Matti are exclusive features of Karun sand, and thus point to ultimate Zagros provenance. Zircon-age fingerprints prove to represent a robust independent tool to trace detritus from the Anatolia-Zagros orogen into the northeastern Rub' al Khali Erg (Fig. 9).

The Rub' al Khali sand sea is delimited to the northeast by the Quaternary fanglomerate apron fed chiefly by Hawasina-type deep-water successions uplifted at the southern front of the northern Oman thrust belt (Maizels and McBean 1990; Blechschmidt et al. 2009). This gravelly pediment surface, formed by prolonged wind deflation that removed finer grains toward the Wahiba Sands, is mantled by small pebbles and granules of chert, with subordinate limestone, shale to sandstone, and minor volcanic and metavolcanic clasts (Fig. 4D). Dunes advancing on such substrate at the northeastern edge of the erg do contain locally slightly more abundant chert and enstatite grains, but their composition is altogether similar to Ardah dunes inland. Heavy-mineral concentration tends to decrease from Shaybah to Ardah, and ultramafic rock fragments remain rare, which rules out additional contribution from heavy-mineral-rich mafic and ultramafic rocks of the Sema'il ophiolite. Sediment supply from northern Oman ophiolites to Rub' al Khali dunes, overemphasized by previous authors (e.g., El-Sayed 1999, 2000), is in fact negligible even at the very edge of the sand sea $(0.5 \pm 0.3 \%$ of bulk sand), and null in the Uruq al Mutaridah inland. Ophiolite-derived clasts 
605

606

607

608

609

610

611

612

613

614

615

616

617

618

619

620

621

622

623

624

625

626

627

628

629

630

increase in fanglomerates northward (Farrant et al. 2015), and yet detritus ultimately derived from the Oman obduction orogen reaches at most, and only locally close to the mountain front, $5-15 \%$ of feldspatho-litho-quartzose to feldspatho-quartzo-lithic sand of UAE dunes and beaches.

\section{SAND PROVENANCE IN THE SOUTHWESTERN RUB' AL KHALI}

Wadi sand in central to southern Saudi Arabia ranges from feldspatho-quartzose basementaclastic (Wadi Hubuna and Qatan) to recycled quartzose (Wadi Hima) and quartzo-lithic carbonaticlastic (Wadi Hanifa/Sahba, Ushayrab, Maqran, and Sulayyil), reflecting provenance from the Arabian shield and its Paleozoic to Jurassic sedimentary covers in different proportions. Sand of Wadi ad Dawasir is a mixture of detritus derived from crystalline basement, siliciclastic and carbonate cover strata diluted by finer-grained wind-blown quartz. Sand of Wadi Najran is largely recycled from Paleozoic siliciclastic covers.

Detrital signatures of wadi sands are much more varied than those of sand sheets and dunes in the adjacent sand sea, characterized by dominant quartz and poor heavy-mineral suites with zircon, tourmaline and rutile. Such a concentration of chemically durable minerals reflects extensive recycling of mostly Paleozoic siliciclastic units, and is thus inherited chiefly from the CambroOrdovician period of intense weathering that followed the end of the Neoproterozoic orogeny (Avigad et al. 2005). Most dunes, however, are not as quartzose as the Wajid Sandstone, and heavymineral concentration is one to two orders-of-magnitude higher with much lower ZTR indices $(7 \pm 4$ vs. 54). This indicates an additional contribution from the Arabian shield, estimated to account for $\sim 20 \%$ of dune sand. Moreover, only the coarse tail of the size distribution is invariably quartzose to purely quartzose, whereas the fine tail may contain significant feldspar, carbonate and diverse other lithic grains. Heavy-mineral concentration, highest in sand sheets and low dunes along the western edge of the desert where amphibole is most abundant, tends to decrease toward the heart of the sand sea (corr. coeff. $\sim 0.8$, sign. lev. $0.1 \%$ ), where suites become progressively closer to those in the 
631 northeastern Rub' al Khali. Some similarities in petrographic and heavy-mineral modes between the 632 southwestern and northeastern Rub' al Khali may suggest homogenization at the regional scale 633 within the sand sea. Detrital modes, however, do not indicate extensive mixing with orogenic 634 detritus transported all across the erg. The few small carbonate grains found in southwestern Rub' al 635 Khali dunes may be blown by dominant Shamal winds from as far as the Gulf and beyond, but also 636 derived locally from carbonate outcrops of Jabal Tuwaiq and the Hadhramaut Arch or supplied by 637 Wadi ad Dawasir. Also the few sedimentary/metasedimentary, metavolcanic/metabasite and chert 638 grains, equally concentrated in the fine tail of the size distribution (Fig. 6A,B), may be derived 639 either locally from the Arabian basement and cover strata or long-distance ultimately from as far as 640 the Anatolia-Zagros orogen. Detrital zircons mostly yielded Early Paleozoic and Precambrian ages, 641 indicating overwhelming supply from Arabian sources. The rare occurrence of zircon grains 642 yielding Eocene to Carboniferous ages, however, suggests that Arabian detritus may not be 643 exclusive even along the southwestern edge of the Rub' al Khali. The possibility of eolian transport 644 by Shamal winds for $\sim 1000 \mathrm{~km}$ across the sand sea, and ultimate provenance of a minor part of dune sand from as far as the Anatolia-Zagros orogen cannot be ruled out.

646

\section{CONCLUSIONS}

By using petrographic, heavy-mineral and geochronological signatures of sand-sized grains we have documented an exceptional case of transcontinental multi-step sediment transport in hyperarid climatic conditions along a particularly complex routing system (Fig. 11). Detritus shed by the Anatolia-Zagros orogen developed on the Eurasian upper plate after collision with Arabia in the Paleogene did not only reach the associated Gulf foreland basin on the lower plate via the Euphrates-Tigris system and other rivers draining the Iranian Zagros, but it was blown inland by dominant Shamal winds to reach well into the Arabian foreland. Sediment dispersal over a cumulative distance of up to $4000 \mathrm{~km}$ from Anatolian headwaters took place in multiple steps 
657 through the Quaternary, involving repeated eolian reworking of Quaternary and Neogene foreland-

658 basin deposits during lowstand stages of the Pleistocene and progressive accumulation of dunes in 659 the Rub' al Khali, the largest continuous sand sea on Earth.

660 The extrabasinal sand fraction in Gulf beaches and northeastern Rub' al Khali dunes is ultimately 661 derived from Arabia, Anatolia, and the Zagros in varying proportions. Sediment supply from 662 obducted ophiolites of the northern Oman Mountains is instead detected only locally, and largely 663 negligible overall. Sand of the southwestern Rub' al Khali is dominantly Arabian-derived, but 664 similarities of compositional parameters and a few young zircon ages suggest the possibility of 665 long-distance mixing with sand blown all the way from the Gulf coast to as far as the southwestern 666 edge of the sand sea. Besides the progressive dilution inland by coarser quartzose sand mostly 667 recycled from Arabian siliciclastic covers, mechanical wear during long-distance transport in highenergy eolian environments explains why relatively soft carbonate grains are systematically 669 concentrated in the finer sand class, as observed in beaches and dunes along the Gulf coast and in 670 the northeastern to southwestern Rub' al Khali. The complexity of sediment dispersal patterns, 671 commonly extending across a continent over distances of thousands of kilometers, and the 672 consequent spatial decoupling between diverse detrital sources and the depositional sink must be 673 carefully taken into account when interpreting provenance and dispersal pathways of ancient clastic 674 suites.

675

676

677

678

\section{ACKNOWLEDGMENTS}

Petrographic analyses on several samples were carried out by Danilo Controversio; Stefano Lombardi helped with heavy-mineral analyses and George Peters with U-Pb geochronological analyses. Luca Caracciolo kindly collected the Kuwait beach sand. Information and advice from Kenneth Glennie and assistance in the field by Abduljamiu Olalekan Amao and Ardiansyah Koeshidayatullah is gratefully acknowledged. The article benefited greatly from extremely careful, 
683 excellent constructive comments by reviewers Bill Heins and Tim Lawton and editors Lynn 684 Soreghan and Gary Hampson.

685

686

687 SUPPLEMENTARY MATERIAL

688 Supplementary data associated with this article can be found in the online version, at 689 http://dx.doi. . These include information on sampling sites (Table A1) and the

690 complete bulk-sand petrography (Table A2), heavy-mineral (Table A3), and geochronological

691 datasets (Appendix B). Table captions are contained in Appendix A, which illustrates the approach

692 followed in the calculation of provenance budgets. The Google Earth ${ }^{\mathrm{TM}}$ map of sampling sites 693 Arabia\&Gulf.kmz is also provided.

694 
696

697

698

699

700

701

702

703

704

705

706

707

708

709

710

711

712

713

714

715

716

717

718

719

720

FIGURES

Figure 1. Google Earth ${ }^{\mathrm{TM}}$ map of Arabia and the Anatolia-Zagros orogen showing sample locations. The Euphrates-Tigris-Karun drainage basin is outlined by thick grey line. Thin orange lines indicate dune trends in the Rub' al Khali Erg; thickness of blue lines is proportional to the importance of each river/wadi. The two white dotted arrows indicate traverses across the northwestern and northeastern edges of the Rub' al Khali illustrated by microphotographs $A-B-C$ and $D-E-F$ in Figure 4. Samples labeled with small-case letters around the southwestern edge of the Rub' al Khali refer to microphotographs $a-b-c-d-e-f$ in Figure 5.

Figure 2. Geology of Arabia and the Gulf region (redrawn from Asga-Unesco 1963), where sand seas occupy an area of $\sim 800,000 \mathrm{~km}^{2}$ overall.

Figure 3. Geography of Arabia and the Gulf region. Modern seasonal wind regimes after the Saudi Arabian Wind Energy Atlas cited in Al-Ali (2015).

Figure 4. Petrographic trends along two traverses at the northwestern and northeastern edges of the Rub' al Khali (sample location shown in Fig. 1). Northwestern traverse: A) feldspatho-lithoquartzose Gulf beach sand of largely Anatolia-Zagros provenance; B) bimodal dune sand including Arabian-derived quartz associated with a much finer-grained feldspatho-litho-quartzose carbonaticlastic fraction of largely Anatolia-Zagros provenance; C) feldspatho-quartzose dune sand farther inland lacking carbonate grains. Northeastern traverse: D) cherticlastic gravel pediment fed mostly from the Hawasina Nappes of the northern Oman Mountains; E) dune sand containing abundant tiny carbonate grains; F) feldspatho-quartzose dune sand farther inland lacking carbonate grains. $\mathrm{Q}=$ quartz; $\mathrm{K}=\mathrm{K}$-feldspar; $\mathrm{P}=$ plagioclase; rock fragments: $\mathrm{C}=$ carbonate, $\mathrm{H}=$ chert, $\mathrm{A}=$ arenaceous, $\mathrm{V}=$ volcanic; $\mathrm{p}=$ pyroxene. Blue bar for scale $=250 \mu \mathrm{m}$. 
722 Figure 5. Petrographic signatures and sand sources in the southwestern Rub' al Khali. A) 723 Carbonaticlastic wadi sand from Jurassic strata of Jabal Tuwaiq. B) Mixed basementaclastic and 724 sedimentaclastic wadi sand from the Arabian shield and its cover strata. C) Basementaclastic wadi 725 sand from the Arabian shield. D) Highly quartzose sand recycled from Paleozoic sandstones. E) 726 Paleozoic quartzose sandstone. F) Bimodal feldspatho-quartzose dune sand with a very-fine-grained 727 population containing abundant carbonate grains. $\mathrm{Q}=$ quartz; $\mathrm{K}=\mathrm{K}$-feldspar; $\mathrm{P}=$ plagioclase; $\mathrm{C}=$ 728 carbonate rock fragments. Blue bar for scale $=250 \mu \mathrm{m}$.

Figure 6. Intrasample compositional variability (analytical data provided at bottom of Appendix Tables A2 and A3; petrographic parameters as in Table 1 and Fig. 10). In the QFL plot A, data are centered to allow better visualization (von Eynatten et al. 2002; Comas-Cufí and Thió-Henestrosa 2011). In the compositional biplots $\mathbf{B}$ and $\mathbf{C}$, both multivariate observations (points) and variables (rays) are displayed (Gabriel 1971). The length of each ray is proportional to the variability of the parameter in the data set. If the angle between two rays is close to $0^{\circ}, 90^{\circ}$, and $180^{\circ}$, then the corresponding parameters are directly correlated, uncorrelated, and inversely correlated, respectively. A, B) Provenance-controlled intrasample variability of petrographic modes is regulated principally by increasing proportions of Arabian-derived quartzose detritus with grain size relatively to either finer-grained lithic-rich sedimentaclastic orogenic detritus in dunes inland of Sabkha Matti or feldspar-bearing detritus derived from the Arabian shield in southwestern Rub' al

741 Khali dunes. Orogenic detritus fades landward of Shaybah and Ardah, where intrasample 742 compositional variability is less marked. The southernmost Rub' al Khali Sharurah dune shows 743 similar variability pattern as dunes inland of Sabkha Matti, owing to either local addition of mainly 744 sedimentary lithic grains from the Hadhramaut arch or possibly to mixing with eolian sand blown 745 long-distance from the Gulf. C) Intrasample variability of heavy-mineral modes is primarily a 746 settling-equivalence effect (denser minerals concentrate progressively in finer classes) superposed 
747

748

749

750

751

752

753

754

755

756

757

758

759

760

761

762

763

764

765

766

767

on provenance effects. Gulf beaches are richer in clinopyroxene and garnet, southwestern Rub' al Khali dunes in amphibole and zircon. The anomalous correlation patterns with heavy-mineral concentration (low-density tourmaline is inversely correlated as expected, but epidote and garnet should correlate better than less dense amphibole and clinopyroxene) indicates mixing with finergrained detritus enriched in ferromagnesian minerals.

Figure 7. Influence of mechanical wear on downwind compositional changes (data are centered to allow better visualization). Because of mixing with quartz-rich Arabian-derived sand, sedimentary lithics decrease progressively inland from the Gulf to the northeastern Rub' al Khali, but carbonate (Lc) and shale/siltstone grains (Lp) decrease notably faster than tougher chert (Lh). Chert increases from finer to coarser sand classes within dunes inland of Sabkha Matti, which also suggests greater resistance to mechanical wear. Only a little chert from the Oman Mountains is added locally at the eastern edge of the erg; Arabian sources at its western edge may contribute carbonate lithics but no chert.

Figure 8. U-Pb age spectra of detrital zircons (age vs. frequencies plotted as Kernel Density Estimates using the provenance package of Vermeesch et al. 2016). Arabian sources are dominated by Cambrian to Neoproterozoic "Pan-African" zircons and lack post-Devonian zircons, which are common in Euphrates-Tigris-Karun sands. A few zircons as young as the latest Miocene as well as small Oligocene-Eocene, Late Cretaceous, Middle Jurassic, and Permian-Carboniferous clusters found from Gulf beaches to northeastern Rub' al Khali dunes allow us to trace orogenic detritus ultimately derived from the Anatolia-Zagros orogen into the heart of Arabia.

Figure 9. Multidimensional scaling map of Arabian sands based on U-Pb ages of detrital zircons (plotted using the provenance package of Vermeesch et al. 2016). The distance among samples is approximately proportional to the Kolmogorov-Smirnov dissimilarity of their zircon-age spectra; 
773 the 'stress' value of the configuration is $5.9 \%$, indicating a 'good' fit (Vermeesch 2013). The two

774 main ultimate sources of detrital zircons are the Tigris-Euphrates-Karun fluvial system in the north

775 and Arabia with its siliciclastic covers in the west. Zircon grains mix progressively during sand

776 dispersal from north to south to finally reach the Rub' al Khali Erg. Data from northern Arabian

777 deserts, Paleozoic sandstones and the Euphrates-Tigris-Karun river system after Garzanti et al.

$778 \quad(2013 ; 2016)$.

779

780 Figure 10. Provenance analysis. Beaches of the northern Gulf and dunes from the Jafurah to the 781 northeastern Rub' al Khali ergs are derived partly from Mesopotamian sources (Euphrates + Tigris 782 Rivers), with contribution from Arabian sources (mostly Paleozoic siliciclastic strata) rapidly 783 increasing landward and with increasing grain size. Composition of Trucial coast beaches and dunes 784 points to major ultimate supply from the Zagros Mountains along the opposite side of the Gulf 785 (Garzanti et al. 2003). Dunes of the southwestern Rub' al Khali are chiefly Arabian-derived. A) 786 QFL plot (data are centered to allow better visualization). Feldspatho-quartzo-lithic Mesopotamian 787 sands carried by the Euphrates and Tigris Rivers and lithic carbonaticlastic Zagros sands supplied 788 by the Karun and Shatt al Arab are sharply distinct from feldspatho-quartzose and quartzose sands 789 derived from the Arabian shield and its Paleozoic siliciclastic covers. Mainly quartzo-lithic 790 carbonaticlastic detritus shed by Arabian Mesozoic covers contributes little to the dune fields. B) 791 Framework petrography. C) Heavy minerals. Intrasample variability follows the settling792 equivalence-controlled pattern towards decreasing heavy-mineral concentration with increasing 793 grain size in both Taroot beach and Tamani dune samples, but also shows a prominent provenance 794 effect for the Taroot beach, composition moving away from the Mesopotamian field towards the 795 Arabian field with increasing grain size (arrow). D) Petrographic and heavy-mineral signatures 796 combined. $\mathrm{L}=$ lithic grains $(\mathrm{Lvm}=$ volcanic and low-rank metavolcanic; $\mathrm{Lsm}=$ sedimentary and 797 low-rank metasedimentary; Lmfb = high-rank felsic metamorphic and metabasite); op= opaque Fe798 Ti-Cr oxides; other parameters as in Table 1. 
800 Figure 11. The complex source-to-sink system of Arabian sands. The twelve mineralogical maps 801 illustrate key petrographic and heavy-mineral data; circles stand for sample groups, with diameter 802 proportional to size of source or sink, color fill proportional to mineral abundance, and color outline representing facies $($ green $=$ river/wadi; blue $=$ beach; orange $=$ eolian dune/sand sheet; purple $=$ pediment). Reconstructed in the central panel are patterns of sand dispersal and mixing (arrow thickness indicatively proportional to estimated contribution). Only ultimate sources of detritus are shown, because our data cannot reveal multiple recycling of Pleistocene eolianites and Miocene sandstones. Sand contributions from Anatolia, Zagros Mountains, Arabian Shield, Sama'il ophiolite, or even from Hawasina cherts and local outcrops of carbonate rocks or Neogene basalts are identified more readily at the periphery of sand seas, whereas monocrystalline quartz becomes rapidly dominant toward the core of all major Arabian ergs. Quartz recycled from Paleozoic or younger siliciclastic strata thus represents by far the dominant source of sand to Arabian deserts, 812 reflecting the high sand-generation potential of quartz-rich sandstones.

814 Table 1. Key petrographic and mineralogical parameters of sands from Mesopotamian rivers, Gulf 815 beaches, and Arabian dune fields and widyan (Fig. 1; including data from Garzanti et al. 2001, $8162003,2013,2016) . \mathrm{N}^{\circ}=$ number of samples; $\mathrm{Q}=$ quartz; $\mathrm{F}=$ feldspars $(\mathrm{KF}=\mathrm{K}$-feldspar; $\mathrm{P}=$ 817 plagioclase); $\mathrm{L}=$ lithic grains $(\mathrm{Lc}=$ carbonate; $\mathrm{Lh}=$ chert; $\mathrm{Lms}=$ other sedimentary and 818 metasedimentary; $\mathrm{Lmv}=$ volcanic, metavolcanic, and metabasite; $\mathrm{Lu}=$ ultramafic). $\mathrm{HM}=$ heavy 819 minerals. tHMC $=$ transparent Heavy-Mineral Concentration. ZTR $=$ zircon + tourmaline + rutile; 820 Ep = epidote; Grt = garnet CSKA = chloritoid + staurolite + andalusite + kyanite + sillimanite; $821 \mathrm{Amp}=$ amphibole; $\mathrm{Cpx}=$ clinopyroxene; $\mathrm{En}=$ enstatite; $\mathrm{Hy}=$ hypersthene; $\mathrm{Ol}=$ olivine; $\mathrm{Sp}=\mathrm{Cr}-$ spinel; \&tHM = other transparent heavy minerals (titanite, apatite, minor Ti oxides and monazite). Full datasets provided in Appendix Tables A2 and A3. 


\section{REFERENCES}

826

827

828

829

830

831

832

833

834

835

836

837

838

839

840

841

842

843

844

845

846

847

848

849

850

851

852

853

854

855

856

857

858

859

Ahmed, E.A., Soliman, M.A., Alsharhan, A.S., and Tamer, S., 1998, Mineralogical characteristics of the dunes in the Eastern Province of Abu Dhabi, United Arab Emirates, in Alsharhan, A.S., Glennie, K.W., Whittle, G.L., and Kendall, C.G.St.C., eds., Quaternary Deserts and Climatic Change: Rotterdam, Balkema, p. 85-90.

Al-Ajmi, H.F., Keller, M., Hinderer, M., and Filomena, C.M., 2015, Lithofacies, depositional environments and stratigraphic architecture of the Wajid Group outcrops in southern Saudi Arabia: GeoArabia, v. 20, p. 49-94.

Al-Ali, A.M., 2015, Use of spatial technologies to study the winds' directions in Rub' Al-Khali Desert, Saudi Arabia: Journal of Earth Science and Engineering, v. 5, p. 372-381.

Al-Saad, H., Nasir, S., Sadooni, F., and Alsharhan A.S., 2002, Stratigraphy and sedimentology of the Hofuf Formation in the State of Qatar in relation to the tectonic evolution of the East Arabian Block: Neues Jahrbuch für Geologie und Paläontologie-Monatshefte, v. 7, p. 426-448.

Alsharhan, A.S., and Kendall, C.G.St.C., 2003, Holocene coastal carbonates and evaporites of the southern Arabian Gulf and their ancient analogues: Earth-Science Reviews, v. 61, p. 191-243.

Alsharhan, A.S., and Nairn, A.E.M., 1997, Sedimentary basins and petroleum geology of the Middle East: Amsterdam, Elsevier, 942 p.

Al-Sulaimi, J.S., and Pitty, A.F., 1995, Origin and depositional model of Wadi Al-Batin and its associated alluvial fan, Saudi Arabia and Kuwait: Sedimentary Geology, v. 97, p. 203-229.

Andò, S., and Garzanti, E., 2014, Raman spectroscopy in heavy-mineral studies: Geological Society London, Special Publication 386, p. 395-412.

Anton, D., 1983, Modern eolian deposits of the eastern province of Saudi Arabia, in Brookfield, M.E., and Ahlbrandt, T.S., eds., Eolian sediments and processes: Amsterdam, Elsevier, Developments in Sedimentology, v. 38, p. 365-378.

Asga-Unesco, 1963, Geological map of Africa, sheet N.3, scale 1:5,000,000: Association of African Geological Surveys, United Nations Educational, Scientific and Cultural Organization, Paris.

Avigad, D., Kolodner, K., McWilliams, M.O., Persing, H.M., and Weissbrod, T., 2003, Origin of northern Gondwana Cambrian sandstone as revealed by SHRIMP dating of detrital zircons: Geology, v. 31, p. 227-230.

Avigad, D., Sandler, A., Kolodner, K., Stern, R.J., McWilliams, M.O., Miller, N., and Beyth, M., 2005, Mass-production of Cambro-Ordovician quartz-rich sandstone as a consequence of chemical weathering of Pan-African terranes: environmental implications: Earth and Planetary Science Letters, v. 240, p. 818-826.

Baltzer, F., and Purser, B.H., 1990, Modern alluvial fan and deltaic sedimentation in a foreland tectonic setting: the lower Mesopotamian plain and the Arabian Gulf: Sedimentary Geology, v. 67, p. 175-197. 
860

861

862

863

864

865

866

867

868

869

870

871

872

873

874

875

876

877

878

879

880

881

882

883

884

885

886

887

888

889

890

891

892

893

894

895

896

Béchennec, F., Le Métour, J., Rabu, D., Bourdillon-De-Grissac, C., De Wever, P., Beurrier, M., and Villey, M., 1990, The Hawasina Nappes: stratigraphy, palaeogeography and structural evolution of a fragment of the south-Tethyan passive continental margin: Geological Society London, Special Publication 49, p. 213-223.

Bibi, F., Hill, A., Beech, M., and Yasin, W., 2013, Late Miocene fossils from the Baynunah Formation, United Arab Emirates: summary of a decade of new work, in Wang, X., Flynn, L.J., and Fortelius, M., eds., Fossil mammals of Asia: Neogene biostratigraphy and chronology, p. 583-594.

Bishop, M.A., 2013, Dune field development, interactions and boundary conditions for crescentic and stellate megadunes of the Al Liwa Basin, the Empty Quarter: Earth Surface Processes and Landforms, v. 38, p. 183-191.

Blechschmidt, I., Matter, A., Preusser, F., and Rieke-Zapp, D., 2009, Monsoon triggered formation of Quaternary alluvial megafans in the interior of Oman: Geomorphology, v. 110, p. 128-139.

Cantrell, D. L., Nicholson, P.G., Hughes, G.W., Miller, M.A., Bhullar, A.G., Abdelbagi, S.T., and Norton, A.K., 2014, Tethyan petroleum systems of Saudi Arabia: American Association of Petroleum Geologists, Memoir 106, p. 613-639.

Comas-Cufí, M., and Thió-Henestrosa, S., 2011, CoDaPack 2.0: a stand-alone, multiplatform compositional software. In: CoDaWork'11: 4th International Workshop on Compositional Data Analysis. Sant Feliu de Guíxols, Spain.

Dickinson, W.R., 1988, Provenance and sediment dispersal in relation to paleotectonics and paleogeography of sedimentary basins, in Kleinspehn, K.L., and Paola, C., eds., New perspectives in basin analysis: New York, Springer, p. 3-25.

Edgell, H.S., 2006, Arabian deserts: nature, origin and evolution: Dordrecht, Springer, 591 p.

El-Sayed, M.I., 1999, Sedimentological characteristics and morphology of the aeolian sand dunes in the eastern part of the U.A.E.: a case study from Ar Rub' Al Khali: Sedimentary Geology, v. 123, p. 219238.

El-Sayed, M.I., 2000, The nature and possible origin of mega-dunes in Liwa, Ar Rub' Al Khali, U.A.E.: Sedimentary Geology, v. 134, p. 305-330.

Evans, G., 2011, An historical review of the Quaternary sedimentology of the Gulf (Arabian/Persian Gulf) and its geological impact, in Kendall, C.G.St, and Alsharhan, A., eds., Quaternary carbonate and evaporite sedimentary facies and their ancient analogues: a tribute to D.J. Shearman: Chichester, WileyBlackwell, International Association of Sedimentologists, Special Pubblication 43, p. 11-44.

Farrant, A.R., Ellison, R.A., Thomas, R.J., Pharaoh, T.C., Newell, A.J., Goodenough, K.M., Lee, J.R., and Knox, R.O.B., 2012, The Geology and Geophysics of the United Arab Emirates. Volume 6: Geology of the western and central United Arab Emirates: British Geological Survey, v. 6, Keyworth, Nottingham.

Farrant, A.R., Duller, G.A., Parker, A.G., Roberts, H.M., Parton, A., Knox, R.W., and Bide, T., 2015, Developing a framework of Quaternary dune accumulation in the northern Rub'al-Khali, Arabia: Quaternary International, v. 382, p. 132-144. 
897

898

899

900

901

902

903

904

905

906

907

908

909

910

911

912

913

914

915

916

917

918

919

920

921

922

923

924

925

926

927

928

929

930

931

932

Friend, P.F., 1999. Rivers of the Lower Baynunah Formation, Emirate of Abu Dhabi, United Arab Emirates. Fossil vertebrates of Arabia, with emphasis on the Late Miocene faunas, geology, and palaeoenvironments of the Emirate of Abu Dhabi, United Arab Emirates: New Haven, Yale University Press, p. 39-49.

Fryberger, S.G., Al-Sari, A.M., and Clisham, T.J., 1983, Eolian dune, interdune, sand sheet, and siliciclastic sabkha sediments of an offshore prograding sand sea, Dhahran area, Saudi Arabia: American Association of Petroleum Geologists Bulletin, v. 67, p. 280-312.

Fryberger, S.G., Al-Sari, A.M., Clisham, T.J., Rizvi, S.A.R., and Al-Hinai, K.G., 1984, Wind sedimentation in the Jafurah sand sea, Saudi Arabia: Sedimentology, v. 31, p. 413-431.

Gabriel, K.R., 1971, The biplot graphic display of matrices with application to principal component analysis: Biometrika, v. 58, p. 453-467.

Galehouse, J.S., 1971, Point counting, in Carver, R.E., ed., Procedures in sedimentary petrology: New York, Wiley, p. 385-407.

Garzanti, E., 1991, Non-carbonate intrabasinal grains in arenites: their recognition, significance and relationship to eustatic cycles and tectonic setting: Journal of Sedimentary Petrology, v. 61, p. 959-975.

Garzanti, E., 2016, From static to dynamic provenance analysis - Sedimentary petrology upgraded: Sedimentary Geology, v. 336, p. 3-13.

Garzanti E., 2017, The maturity myth in sedimentology and provenance analysis: Journal of Sedimentary Research, v. 87, p. 353-365.

Garzanti, E., and Andó, S., 2007, Heavy-mineral concentration in modern sands: implications for provenance interpretation, in Mange, M.A., and Wright, D.T., eds., Heavy Minerals in Use: Amsterdam, Elsevier, Developments in Sedimentology, v. 58, p. 517-545.

Garzanti, E., and Vezzoli, G., 2003, A classification of metamorphic grains in sands based on their composition and grade: Journal of Sedimentary Research, v. 73, p. 830-837.

Garzanti, E., Vezzoli, G., Andò, S., and Castiglioni, G., 2001, Petrology of rifted-margin sand (Red Sea and Gulf of Aden, Yemen): The Journal of Geology, v. 109, p. 277-297.

Garzanti, E., Vezzoli, G., and Andò, S., 2002, Modern sand from obducted ophiolite belts (Oman, U.A.E.): The Journal of Geology, v. 110, p. 371-391.

Garzanti, E., Andó, S., Vezzoli, G., and Dell'Era, D., 2003, From rifted margins to foreland basins: investigating provenance and sediment dispersal across desert Arabia (Oman, UAE): Journal of Sedimentary Research, v. 73, p. 572-588.

Garzanti E., Andò S., and Vezzoli G., 2008, Settling equivalence of detrital minerals and grain-size dependence of sediment composition: Earth and Planetary Science Letters, v. 273, p. 138-151.

Garzanti, E., Andò, S., Vezzoli, G., Lustrino, M., Boni, M., and Vermeesch, P., 2012a, Petrology of the Namib sand sea: long-distance transport and compositional variability in the wind-displaced Orange Delta: Earth-Science Reviews, v. 112, p. 173-189. 
933

934

935

936

937

938

939

940

941

942

943

944

945

946

947

948

949

950

951

952

953

954

955

956

957

958

959

960

961

962

963

964

965

966

967

968

Garzanti, E., Resentini, A., Vezzoli, G., Andó, S., Malusà, M., and Padoan, M., 2012b, Forward compositional modelling of alpine orogenic sediments: Sedimentary Geology, v. 280, p. 149-164.

Garzanti, E., Vermeesch, P., Andó, S., Vezzoli, G., Valagussa, M., Allen, K., Khadi, K.A., and Al-Juboury, I.A., 2013, Provenance and recycling of Arabian desert sand: Earth-Science Reviews, v. 120, p. 1-19.

Garzanti, E., Vermeesch, P., Andò, S., Lustrino, M., Padoan, M., and Vezzoli, G., 2014, Ultra-long distance littoral transport of Orange sand and provenance of the Skeleton Coast Erg (Namibia): Marine Geology, v. 357, p. 25-36.

Garzanti, E., Andó, S., Padoan, M., Vezzoli, G., and El Kammar, A., 2015, The modern Nile sediment system: processes and products: Quaternary Science Reviews, v. 130, p. 9-56.

Garzanti, E., Al-Juboury, A.I., Zoleikhaei, Y., Vermeesch, P., Jotheri, J., Akkoca, D.B., Obaid, A.K., Allen, M.B., Andò, S., Limonta, M., Padoan, M., Resentini, A., Rittner, M., and Vezzoli, G., 2016, The Euphrates-Tigris-Karun river system: provenance, recycling and dispersal of quartz-poor foreland-basin sediments in arid climate: Earth-Science Reviews, v. 162, p. 107-128.

Glennie, K.W., 1998, The desert of southeast Arabia: a product of Quaternary climatic change, in Alsharhan, A.S., Glennie, K.W., Whittle, G.L., and Kendall, C.G.St.C., eds., Quaternary Deserts and Climatic Change: Rotterdam, Balkema, p. 279-291.

Glennie, K.W., and Singhvi, A.K., 2002, Event stratigraphy, paleoenvironment and chronology of SE Arabian deserts: Quaternary Science Reviews, v. 21, p. 853-869.

Glennie, K.W., Boeuf, M.G.A., Hughes-Clarke, M.W., Moody-Stuart, M., Pilar, W.F.H., and Reinhardt, B.M., 1974, Geology of the Oman Mountains: The Hague, Verhandelingen van het Koninklijk Nederlands Geologisch Mijnbouwkundig Genootschap, Transactions 31, 423 p.

Goudie, A.S., Colls, A., Stokes, S., Parker, A., White, K., and Al-Farraj, A., 2000, Latest Pleistocene and Holocene dune construction at the north-eastern edge of the Rub Al Khali, United Arab Emirates: Sedimentology, v. 47, p. 1011-1021.

Griffin, W.L., Powell, W.J., Pearson, N.J., and O'Reilly, S.Y., 2008, GLITTER: data reduction software for laser ablation ICP-MS, in Sylvester, P., ed., Laser ablation-ICP-MS in the earth sciences: current practices and outstanding issues: Mineralogical Association of Canada, Short Course 40, p. 204-207.

Hadley, D.G., Brouwers, E.M., Bown, T.M., 1998. Quaternary paleodunes, Arabian Gulf coast, Abu Dhabi Emirate: age and paleoenvironmental evolution. In: Alsharhan, A.S., Glennie, K.W., Whittle, G.L., Kendall, C.G.St.C. (Eds.), Quaternary Deserts and Climatic Change. Balkema, Rotterdam, pp. 123-139.

Harrell, J., and Blatt, H., 1978, Polycrystallinity: effect on the durability of detrital quartz: Journal of Sedimentary Petrology, v. 48, p. 25-30.

Hill, A., Bibi, F., Beech, M., and Al Tikriti, W.Y., 2012, Before archaeology: life and environments in the Miocene of Abu Dhabi, in Potts, D., Hellyer, P., eds., Fifty years of Emirates archaeology: Abu Dhabi, Ministry of Culture, Youth and Community Development, p. 20-33.

Holm, D.A., 1960, Desert geomorphology of the Arabian Peninsula: Science, v. 132, p. 1369-1379. 
969

970

971

972

973

974

975

976

977

978

979

980

981

982

983

984

985

986

987

988

989

990

991

992

993

994

995

996

997

998

999

1000

1001

1002

1003
Hubert, J.F., 1962, A zircon-tourmaline-rutile maturity index and the interdependence of the composition of heavy mineral assemblages with the gross composition and texture of sandstones: Journal of Sedimentary Petrology, v. 32, p. 440-450.

Ingersoll, R.V., Bullard, T.F., Ford, R.L., Grimm, J.P., Pickle, J.D., and Sares, S.W., 1984, The effect of grain size on detrital modes: a test of the Gazzi-Dickinson point-counting method: Journal of Sedimentary Petrology, v. 54, p. 103-116.

Ingersoll, R.V., Dickinson, W.R., and Graham, S.A., 2003, Remnant-ocean submarine fans: largest sedimentary systems on Earth, in Chan, M.A., and Archer, A.W., eds., Extreme depositional environments: mega end members in geologic time: Geological Society of America, Special Paper 370, p.191-208.

Johnson, P.R., Andresen, A., Collins, A.S., Fowler, A.R., Fritz, H., Ghebreab, W., Kusky, T., and Stern, R.J., 2011, Late Cryogenian-Ediacaran history of the Arabian-Nubian Shield: a review of depositional, plutonic, structural, and tectonic events in the closing stages of the northern East African Orogen: Journal of African Earth Sciences, v. 61, p. 167-232.

Kendall, C.G.St, and Alsharhan, A., 2011, Quaternary carbonate and evaporite sedimentary facies and their ancient analogues: a tribute to D.J. Shearman: Chichester, Wiley-Blackwell, International Association of Sedimentologists, Special Pubblication 43, 496 p.

Lambeck, K., 1996, Shoreline reconstructions for the Persian Gulf since the last glacial maximum: Earth and Planetary Science Letters, v. 142, p. 43-57.

Limonta, M., Garzanti, E., Resentini, A., Andó, S., Boni, M., and Bechstädt, T., 2015, Multicyclic sediment transfer along and across convergent plate boundaries (Barbados, Lesser Antilles): Basin Research, v. 27, p. 696-713.

Lippard, S.J., Shelton, A.W., and Gass, I.G., 1986, The ophiolites of northern Oman: London, Blackwell, $178 \mathrm{p}$.

Lomando, A.J., 1999, Structural influences on facies trends of carbonate inner ramp systems, examples from Kuwait-Saudi Arabian coast of the Arabian Gulf and northern Yucatan, Mexico: GeoArabia, v. 4, p. 339-360.

Maizels, J., and McBean, C., 1990, Cenozoic alluvial fan systems of interior Oman: palaeoenvironmental reconstruction based on discrimination of palaeochannels using remotely sensed data: Geological Society London, Special Publication 49, p. 565-582.

McBride, E.F., and Picard, D.M., 1987, Downstream changes in sand composition, roundness and gravel size in a short-headed, high-gradient stream, Northwestern Italy: Journal of Sedimentary Petrology, v. 57, p. 1018-1026.

McClure, H.A., 1984, Late Quaternary palaeoenvironments of the Rub' Al Khali: University of London, Ph.D. Thesis, 245 p. 
1004

1005

1006

1007

1008

1009

1010

1011

1012

1013

1014

1015

1016

1017

1018

1019

1020

1021

1022

1023

1024

1025

1026

1027

1028

1029

1030

1031

1032

1033

1034

1035

1036

1037

1038

Morag, N., Avigad, D., Gerdes, A., Belousova, E., and Harlavan, Y., 2011, Crustal evolution and recycling in the northern Arabian-Nubian Shield: new perspectives from zircon Lu-Hf and U-Pb systematics: Precambrian Research, v. 186, p. 101-116.

Nasir, S.J., El-Kassas, I.A., and Sadiq, A.A.M., 1999, Mineralogy and genesis of heavy minerals in coastal dune sands, south eastern Qatar: Qatar University Science Journal, v. 19, p. 184-201.

Picard, M.D., and McBride, E.F., 2007, Comparison of river and beach sand composition with source rocks, Dolomite Alps drainage basins, northeastern Italy: Geological Society of America, Special Paper 420, p. $1-12$.

Pugh, J.M., 1997, The Quaternary desert sediments of the Al Liwa area, Abu Dhabi: University of Aberdeen, Ph.D. Thesis, $316 \mathrm{p}$.

Purser, B.H., 1973, The Persian Gulf; Holocene carbonate sedimentation and diagenesis in a shallow epicontinental sea: New York, Springer, 471 p.

Radies, D., Preusser, F., Matter, A., and Mange, M., 2004, Eustatic and climatic controls on the sedimentary architecture of the Wahiba Sand Sea, Sultanate of Oman: Sedimentology, v. 51, p. 1359-1385.

Rittner, M., Vermeesch, P., Carter, A., Bird, A., Stevens, T., Garzanti, E., Andò, S., Vezzoli, G., Dutt, R., $\mathrm{Xu}, \mathrm{Z}$., and Lu, H., 2016, The provenance of Taklamakan desert sand. Earth and Planetary Science Letters, v. 437, p.127-137.

Rubey, W.W., 1933, The size-distribution of heavy minerals within a water-laid sandstone: Journal of Sedimentary Petrology, v. 3, p. 3-29.

Searle, M.P., James, N.P., Calon, T.J., and Smewing, J.D., 1983, Sedimentological and structural evolution of the Arabian continental margin in the Musandam Mountains and Dibba zone, United Arab Emirates: Geological Society of America Bulletin, v. 94, p. 1381-1400.

Stokes, S., and Bray, H.E., 2005, Late Pleistocene eolian history of the Liwa region, Arabian Peninsula: Geological Society of America Bulletin, v. 117, p. 1466-1480.

Teller, J.T., Glennie, K.W., Lancaster, N., and Singhvi, A.K., 2000, Calcareous dunes of the United Arab Emirates and Noah's flood: the postglacial reflooding of the Persian (Arabian) Gulf: Quaternary International, v. 68, p. 297-308.

Uchupi, E., Swift, S.A., and Ross, D.A., 1999, Late Quaternary stratigraphy, paleoclimate and neotectonism of the Persian (Arabian) Gulf region: Marine Geology, v. 160, p. 1-23.

Vermeesch, P., 2012, On the visualisation of detrital age distributions: Chemical Geology, v. 312-313, p. 190-194.

Vermeesch, P., 2013, Multi-sample comparison of detrital age distributions: Chemical Geology, v. 341, p. $140-146$.

Vermeesch, P., Resentini, A., and Garzanti, E., 2016, An R package for statistical provenance analysis: Sedimentary Geology, v. 336, p. 14-25. 
1039

1040

1041

1042

1043

1044

1045

1046

1047

1048

1049

1050

1051

1052

1053

1054

1055

1056

1057

1058

1059

Vermeesch, P., Rittner, M., Petrou, E., Omma, J., Mattinson, C., Garzanti, E., 2017, QEMSCAN+LAICPMS: a new tool for petrochronology and sedimentary provenance analysis: Geochemistry, Geophysics, Geosystems, in review.

Vincent, P., 2008, Saudi Arabia: an environmental overview: London, Taylor \& Francis/Balkema, 309 p.

von Eynatten, H., Pawlowsky-Glahn, V., and Egozcue, J.J., 2002, Understanding perturbation on the simplex: a simple method to better visualise and interpret compositional data in ternary diagrams: Mathematical Geology, v. 34, p. 249-257.

Walkden, G.M., and Williams, A., 1998, Carbonate ramps and the Pleistocene-Recent depositional systems of the Arabian Gulf, in Wright, V.P., and Burchette, T.P., eds., Carbonate Ramps: Geological Society of London, Special Pubblication 149, p. 43-53.

Wentworth, C.K., 1919, A laboratory and field study of cobble abrasion: The Journal of Geology, v. 27, p. 507-521.

Williams, A.H., and Walkden, G.M., 2002, Late Quaternary highstand deposits of the southern Arabian Gulf: a record of sea-level and climate change: Geological Society London, Special Publication 195, p. 371386.

Zuffa, G.G., 1985, Optical analyses of arenites: influence of methodology on compositional results, in Zuffa, G.G., ed., Provenance of arenites: Dordrecht Reidel, NATO ASI Series 148, p. 165-189.

Zuffa, G.G., Normark, W.R., Serra, F, and Brunner, C.A., 2000, Turbidite megabeds in an oceanic rift valley recording Jökulhlaups of Late Pleistocene glacial lakes of the western United States: The Journal of Geology, v. 108, p. 253-274. 


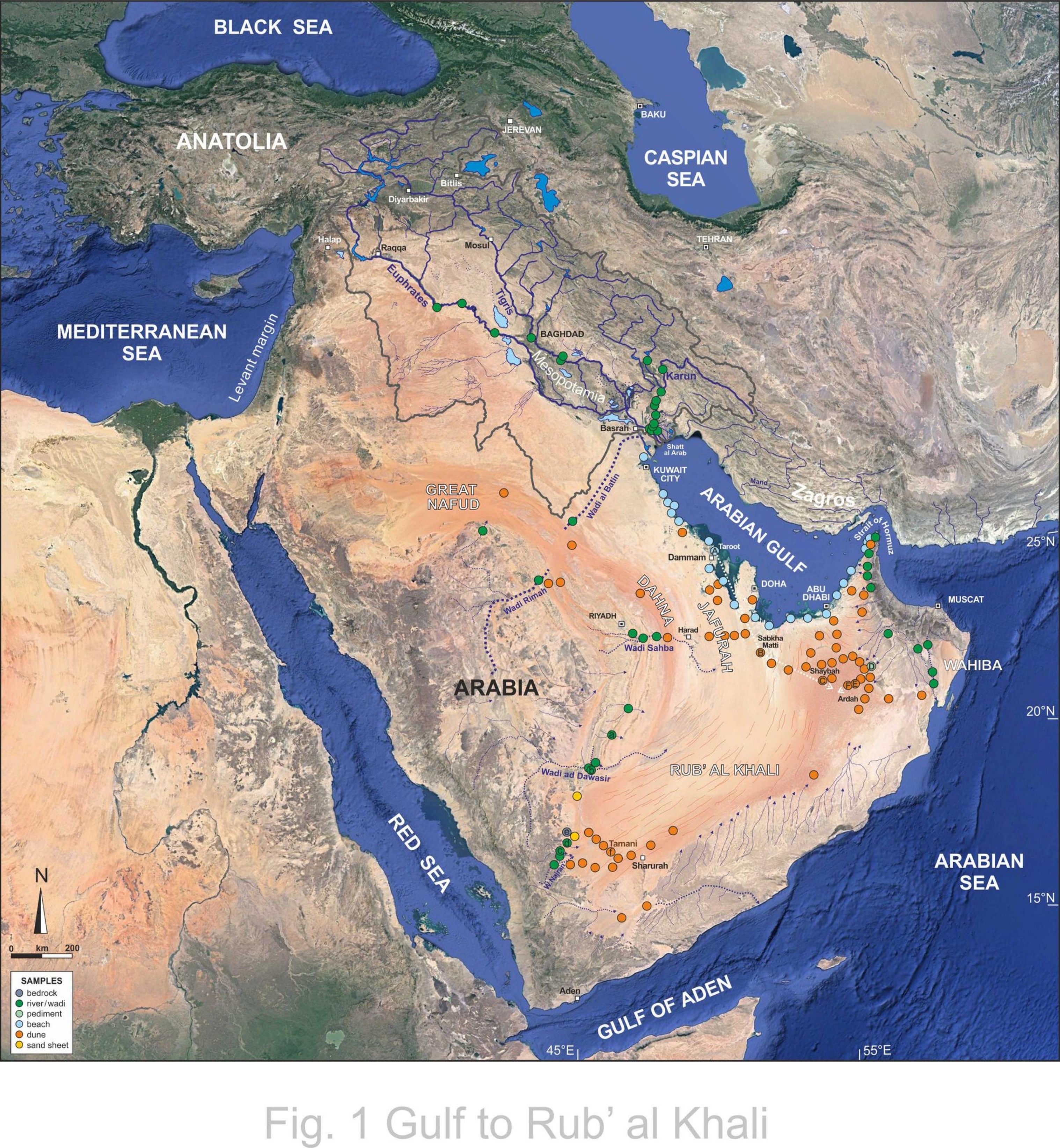



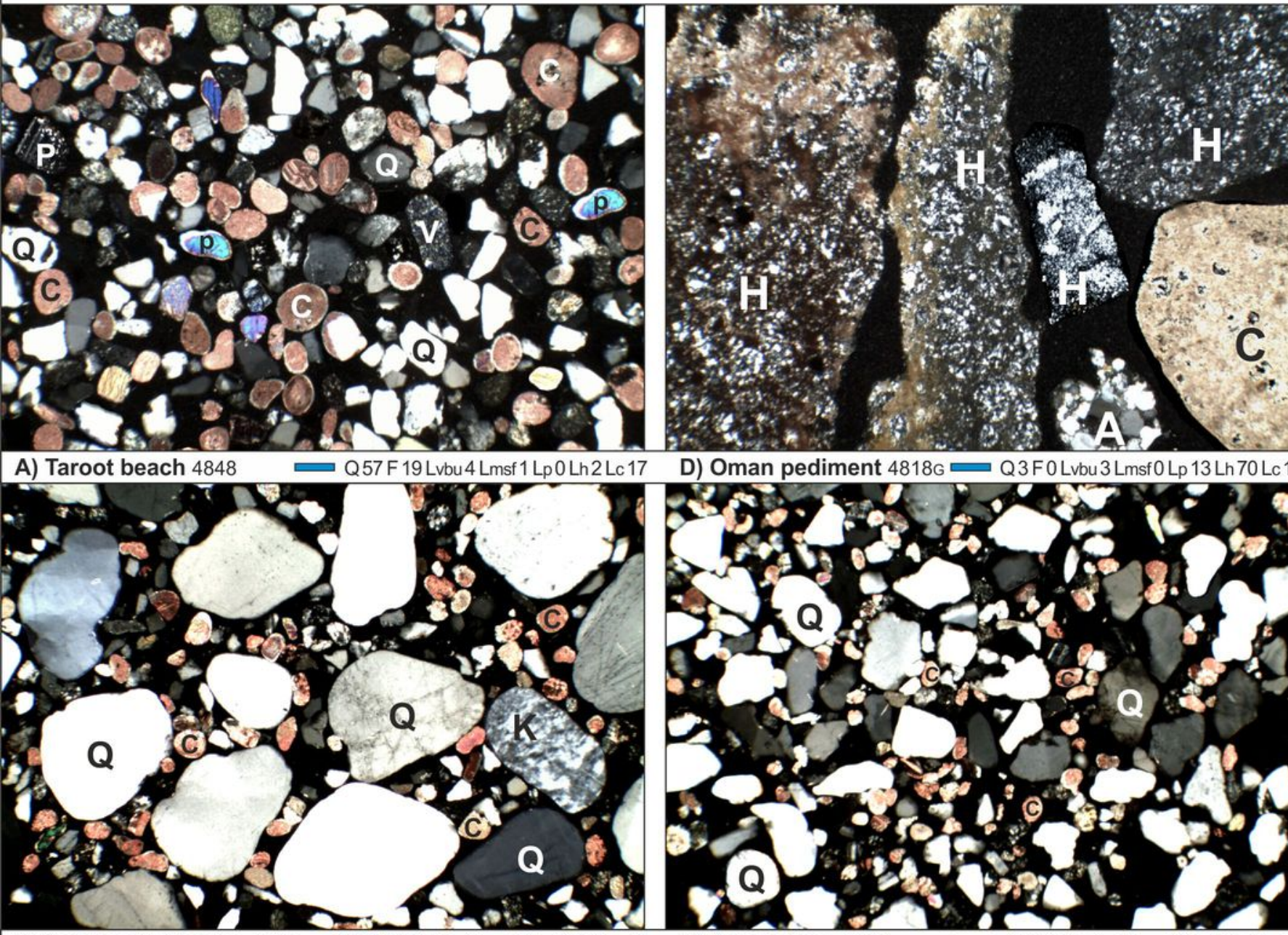

D) Oman pediment $4818 \mathrm{G}=\mathrm{Q} 3 \mathrm{~F} 0 \mathrm{Lvbu} 3 \mathrm{Lmsf} 0 \mathrm{Lp} 13 \mathrm{Lh} 70 \mathrm{Lc} 10$

B) Sabkha Matti dune 4807 Q69F12 Lvbu 0 Lmsf1 Lp0 Lh2 Lc15

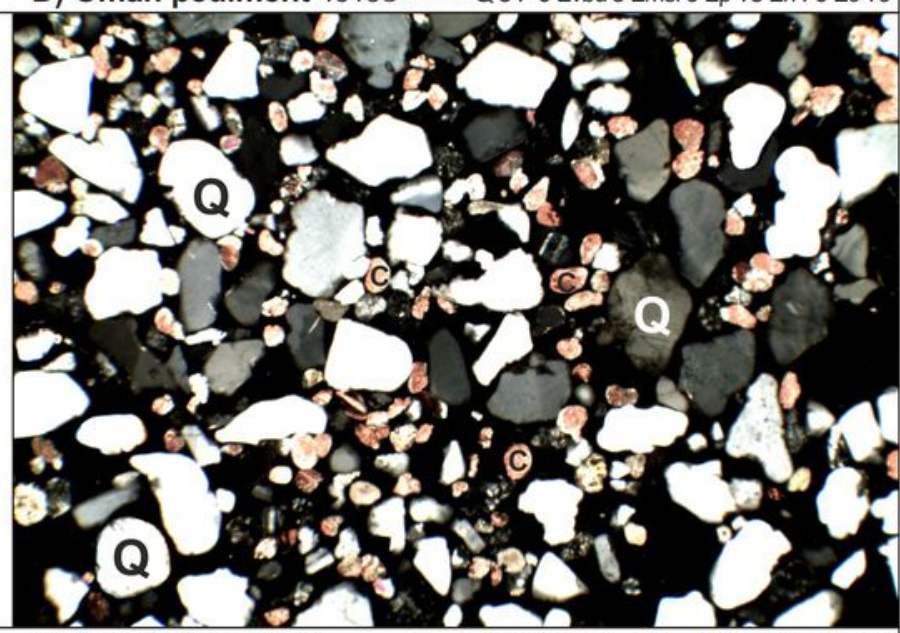

E) Ardah dune 4820

¿ Q82F8Lvbu0Lm

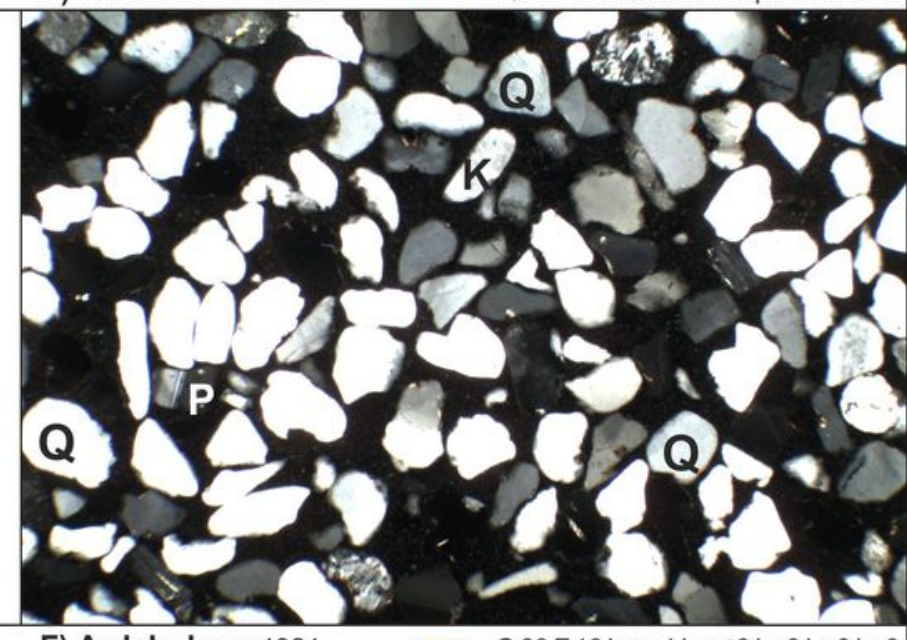

C) Shaybah dune 4813

Q85F 12Lvbu2 Lmsf0Lp0 Lh1 Lc0

F) Ardah dune 4821

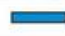

Q83F16 Lvbu1 Lmsf0 Lp0 Lh0 Lc0 
HEAVY MINERALS

Q O Sabkha Mat
O Shaybah Shaybah
Ardah

SW Rub' al Khali Sharurah dune

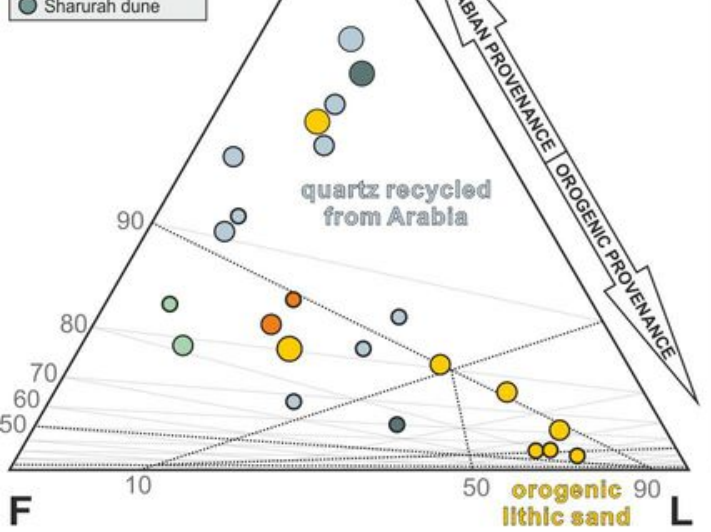

OROGENIC PROVENANCE ARABIAN PROVENANCE

OROGENIC PROVENANCE ARABIAN PROVENANCE
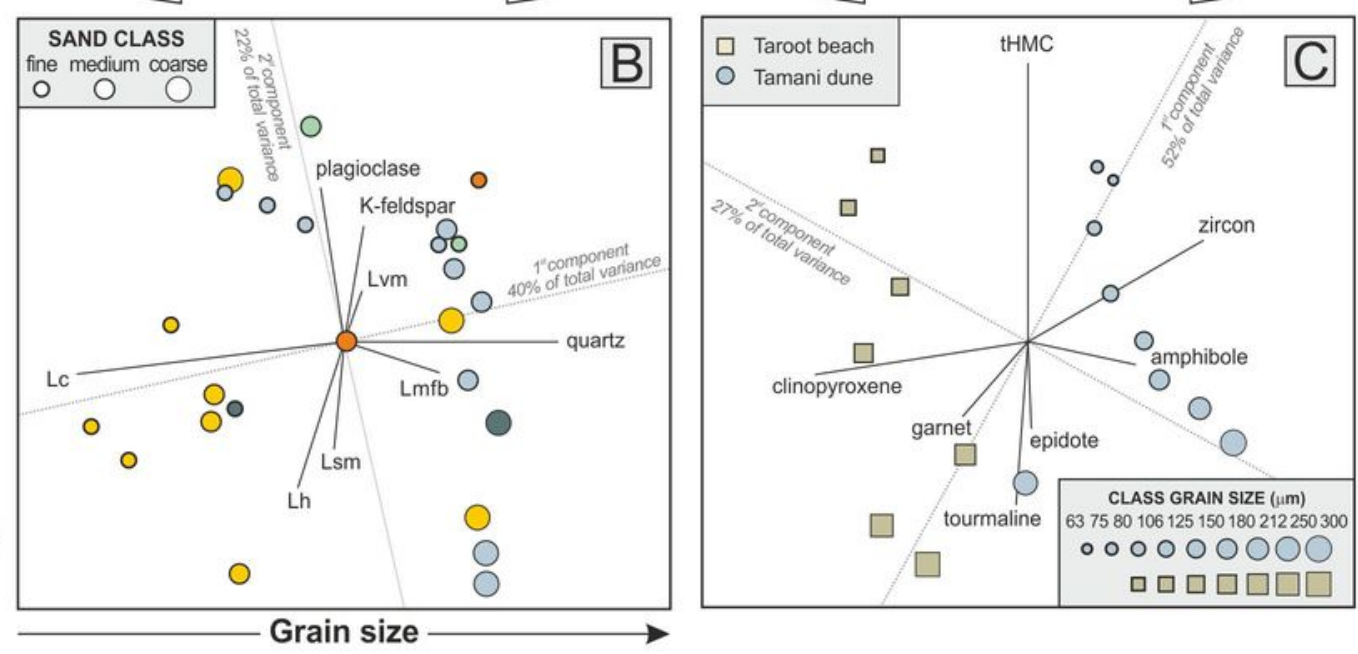

\section{๑}

光.

狖.

, 


\begin{tabular}{|l|c|c|c|c|c|c|}
\hline Miocene & Paleogene & Mesozoic & Paleozoic & Proterozoic & Archean \\
\hline & & & & & & \\
\hline
\end{tabular}

\section{Euphrates River}

$(n=155)$

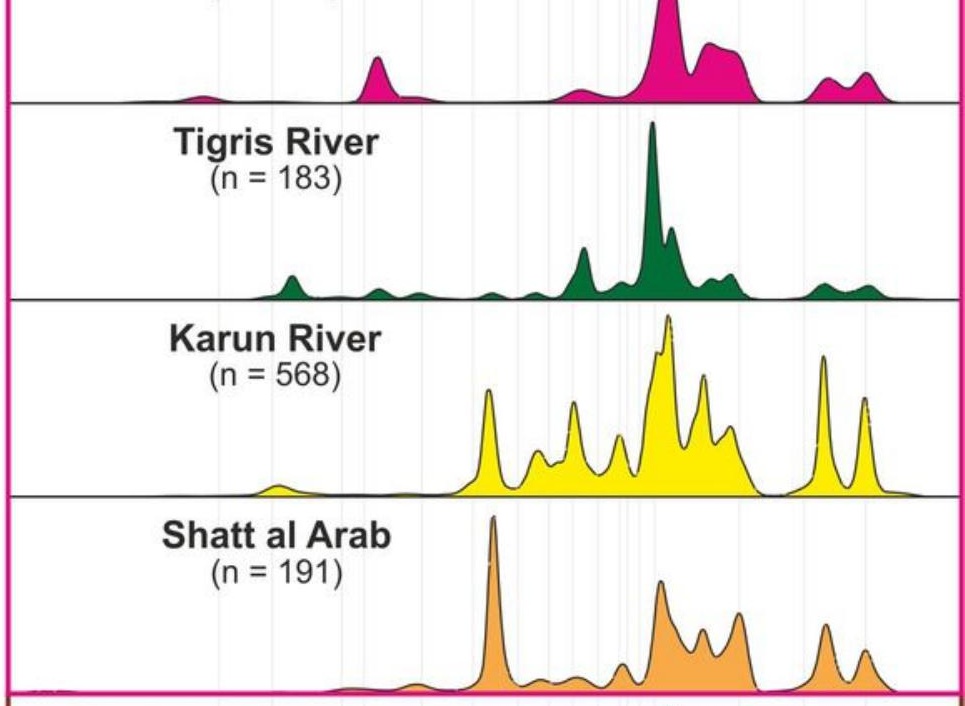

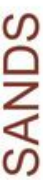

Northern Gulf beaches

$(n=382)$

00000

Jafurah dunes

$(n=539)$

$\theta$ mo mo

Sabkha Matti dunes

$(n=406)$

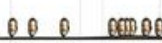
$\mathrm{m}$ e $\mathrm{mrnmm}$

Shaybah dunes

$$
(n=350)
$$

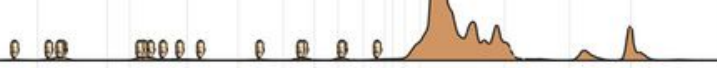

\section{Ardah dunes}

$(n=395$

$\theta \theta$ 99010
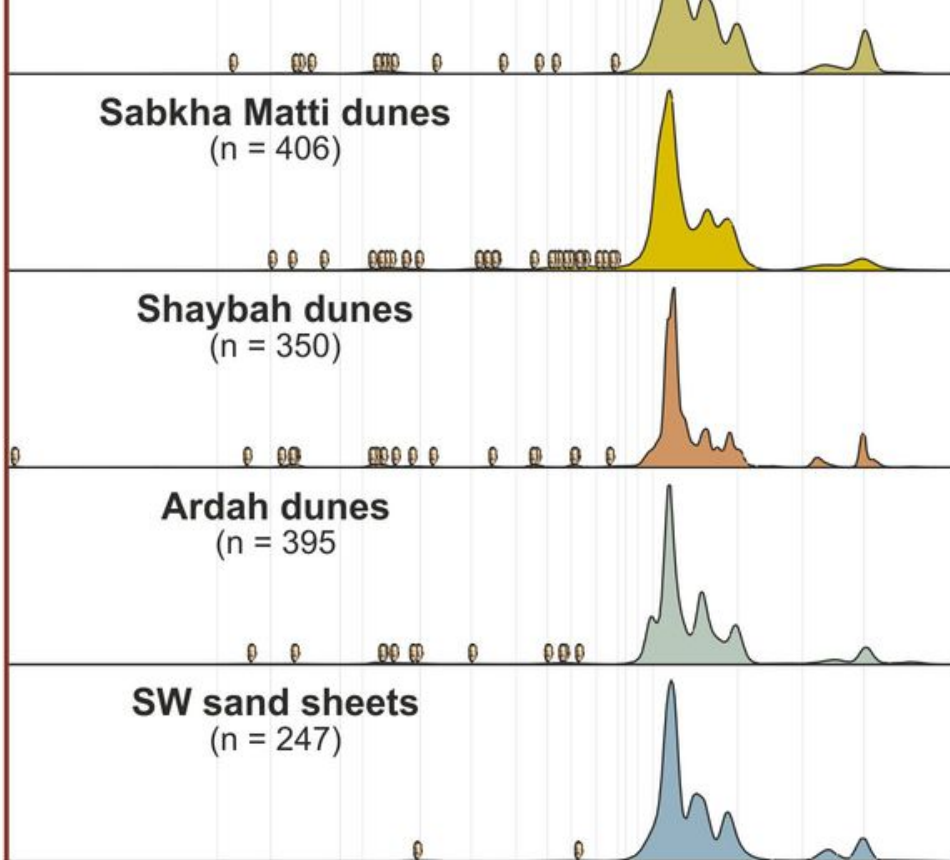

\section{SW Rub' al Khali}

$(n=816)$

$\theta$

SW Arabia widyan

$(n=103)$

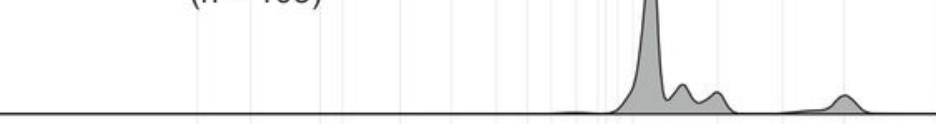

Paleozoic sandstones

$(n=199)$ 

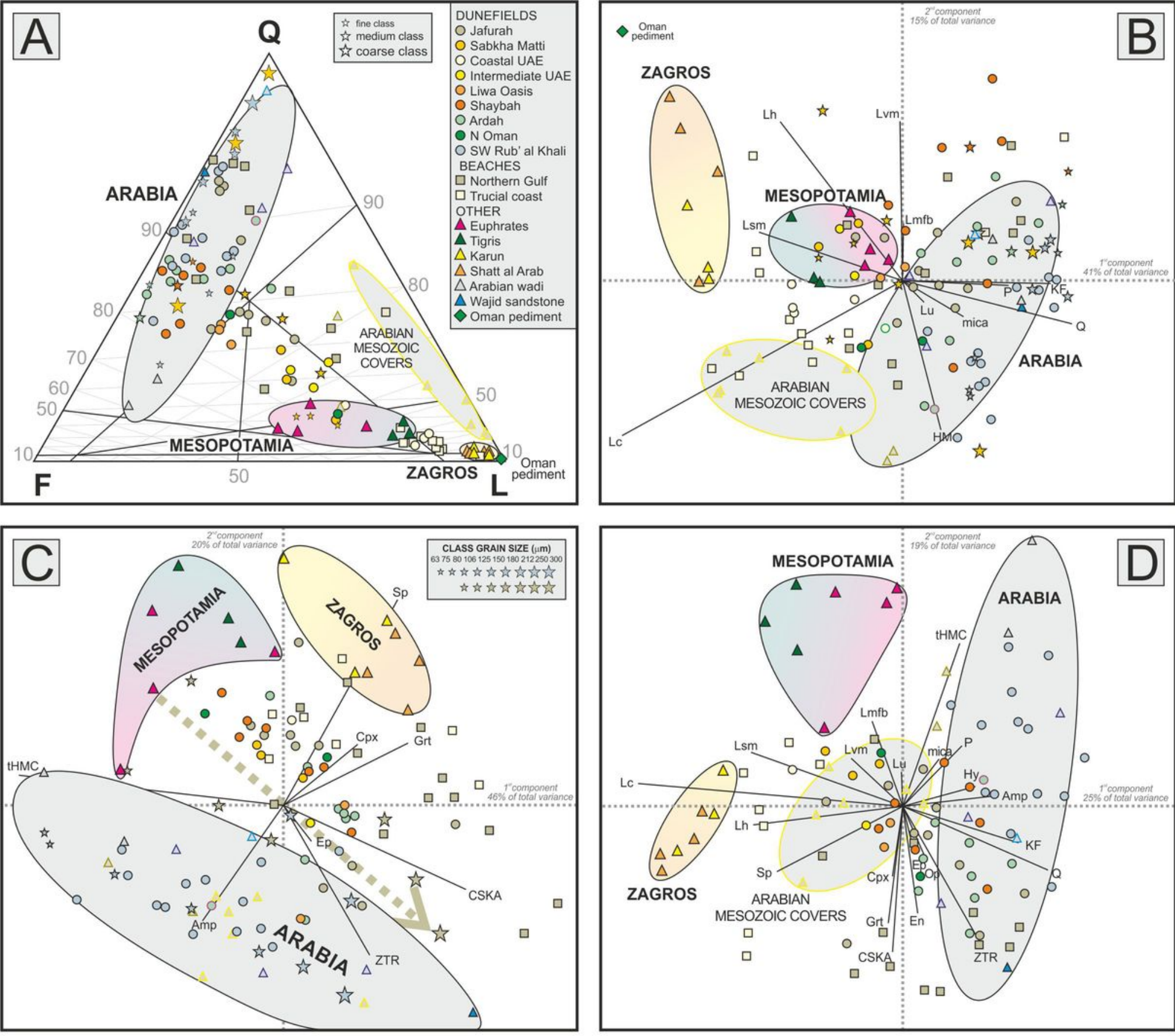


\begin{tabular}{|c|c|c|c|c|c|c|c|c|c|c|c|c|c|c|c|c|c|c|c|c|c|c|c|c|c|c|}
\hline \multicolumn{27}{|l|}{ MESOPOTAMIA } \\
\hline Euphrates River & 3 & 30 & 20 & 14 & 2 & 4 & 17 & 4 & 1 & 7.7 & 100.0 & .78 & 3 & 8.5 & 0 & 24 & 4 & 1 & 29 & 31 & 0 & 8 & 0 & 1 & 1 & 100.0 \\
\hline Tigris River & 3 & 29 & 10 & 30 & 4 & 11 & 7 & 3 & 2 & 5.1 & 100.0 & .80 & 3 & 4.2 & 2 & 36 & 15 & 0 & 26 & 14 & 0 & 0 & 0 & 3 & 3 & 100.0 \\
\hline Karun River & 7 & 11 & 4 & 64 & 13 & 6 & 1 & 0 & 0 & 1.0 & 100.0 & .74 & 7 & 0.7 & 9 & 35 & 9 & 2 & 18 & 13 & 0 & 0 & 0 & 10 & 3 & 100.0 \\
\hline Shatt al Arab & 4 & 9 & 3 & 60 & 16 & 8 & 3 & 0 & 0 & 0.4 & 100.0 & .63 & 4 & 0.3 & 3 & 46 & 7 & 4 & 11 & 21 & 0 & 0 & 0 & 6 & 3 & 100.0 \\
\hline \multicolumn{27}{|l|}{ ARABIAN WIDYAN } \\
\hline Ha'il & 1 & 70 & 25 & 2 & 0 & 1 & 0 & 0 & 0 & 1.7 & 100.0 & .53 & 1 & 0.8 & 4 & 6 & 0 & 0 & 89 & 1 & 0 & 0 & 0 & 0 & 1 & 100.0 \\
\hline Rimah/AI Batin & 2 & 92 & 3 & 4 & 0 & 1 & 1 & 0 & 0 & 0.3 & 100.0 & .33 & 2 & 0.3 & 42 & 9 & 2 & 0 & 33 & 11 & 0 & 0 & 0 & 0 & 2 & 100.0 \\
\hline Sabha/Hanifa & 2 & 45 & 2 & 51 & 0 & 1 & 0 & 0 & 0 & 0.2 & 100.0 & n.d. & 3 & 0.5 & 23 & 16 & 1 & 0 & 51 & 7 & 0 & 0 & 0 & 0 & 3 & 100.0 \\
\hline Ushayrab/Maqran & 2 & 27 & 0 & 71 & 0 & 1 & 0 & 0 & 0 & 0 & 100.0 & n.d. & 2 & 0.2 & 11 & 30 & 3 & 1 & 51 & 4 & 0 & 0 & 0 & 0 & 1 & 100.0 \\
\hline Sulayyil & 1 & 48 & 0 & 48 & 0 & 3 & 0 & 0 & 0 & 0 & 100.0 & n.d. & 1 & 0.6 & 4 & 27 & 1 & 0 & 61 & 2 & 0 & 1 & 0 & 0 & 2 & 100.0 \\
\hline Ad Dawasir & 1 & 46 & 14 & 38 & 0 & 0 & 0 & 0 & 0 & 1.1 & 100.0 & .57 & 2 & 2.1 & 4 & 23 & 1 & 0 & 69 & 2 & 0 & 0 & 0 & 0 & 1 & 100.0 \\
\hline Hima & 1 & 98 & 1 & 0 & 0 & 1 & 0 & 0 & 0 & 0.3 & 100.0 & n.d. & 1 & 0.4 & 3 & 16 & 11 & 0 & 58 & 7 & 1 & 1 & 0 & 0 & 2 & 100.0 \\
\hline Qatan/Hubuna & 2 & 53 & 32 & 1 & 0 & 5 & 3 & 0 & 2 & 4.8 & 100.0 & .68 & 2 & 7.8 & 2 & 35 & 2 & 0 & 50 & 7 & 0 & 2 & 0 & 0 & 2 & 100.0 \\
\hline Najran & 1 & 88 & 9 & 0 & 0 & 1 & 1 & 0 & 1 & 0.3 & 100.0 & .67 & 1 & 2.0 & 2 & 14 & 2 & 1 & 64 & 9 & 0 & 3 & 4 & 0 & 2 & 100.0 \\
\hline Oman & 8 & 8 & 2 & 24 & 11 & 8 & 3 & 34 & 0 & 11 & 100.0 & .83 & 4 & 9.0 & 2 & 28 & 3 & 0 & 16 & 19 & 18 & 3 & 9 & 2 & 0.1 & 100.0 \\
\hline Musandam & 2 & 2 & 0.2 & 95 & 0.2 & 3 & 0 & 0 & 0 & 0 & 100.0 & n.d. & & & & & & & & & & & & & & \\
\hline \multicolumn{27}{|l|}{ GULF BEACHES } \\
\hline Northern Gulf & 12 & 81 & 8 & 8 & 1 & 0 & 2 & 0 & 0 & 0.6 & 100.0 & .34 & 12 & 0.3 & 14 & 29 & 16 & 1 & 13 & 23 & 1 & 1 & 0 & 1 & 2 & 100.0 \\
\hline Trucial coast & 10 & 19 & 9 & 60 & 3 & 4 & 2 & 1 & 0 & 2.1 & 100.0 & .64 & 7 & 0.4 & 3 & 45 & 16 & 1 & 18 & 10 & 5 & 0 & 0 & 1 & 1 & 100.0 \\
\hline \multicolumn{27}{|l|}{ DUNEFIELDS } \\
\hline Dahna-Nafud corridors & 6 & 98 & 2 & 0 & 0 & 0 & 0 & 0 & 0 & 0 & 100.0 & .49 & 6 & 0.2 & 42 & 10 & 2 & 0 & 25 & 15 & 0 & 0 & 0 & 0 & 4 & 100.0 \\
\hline Jafurah & 9 & 81 & 10 & 6 & 0 & 1 & 2 & 0 & 0 & 0.5 & 100.0 & .30 & 9 & 0.8 & 10 & 27 & 10 & 1 & 23 & 24 & 1 & 1 & 0 & 1 & 4 & 100.0 \\
\hline Niqyan Qatar & 1 & 72 & 10 & 15 & 1 & 0 & 1 & 0 & 0 & 0 & 100.0 & .53 & 1 & 0.1 & 3 & 62 & 7 & 4 & 12 & 10 & 1 & 0 & 0 & 1 & 1 & 100.0 \\
\hline Coastal UAE & 3 & 24 & 9 & 58 & 4 & 2 & 1 & 1 & 0 & 1.4 & 100.0 & .53 & 3 & 0.8 & 5 & 43 & 12 & 0 & 22 & 10 & 5 & 1 & 0 & 1 & 1 & 100.0 \\
\hline Eastern UAE & 2 & 55 & 11 & 21 & 1 & 2 & 2 & 6 & 0 & 2.2 & 100.0 & .43 & 2 & 1.3 & 1 & 24 & 5 & 0 & 11 & 15 & 42 & 1 & 1 & 0 & 0 & 100.0 \\
\hline Intermediate belt & 2 & 59 & 14 & 19 & 2 & 3 & 2 & 0 & 0 & 1.3 & 100.0 & .46 & 2 & 0.9 & 8 & 46 & 11 & 1 & 27 & 5 & 1 & 0 & 0 & 0 & 1 & 100.0 \\
\hline Sabkha Matti & 3 & 55 & 15 & 20 & 3 & 2 & 3 & 0 & 0 & 2.2 & 100.0 & .54 & 3 & 1.2 & 5 & 39 & 14 & 1 & 24 & 16 & 0 & 0 & 0 & 0 & 1 & 100.0 \\
\hline Liwa & 2 & 73 & 15 & 6 & 3 & 2 & 1 & 0 & 0 & 1.0 & 100.0 & .48 & 2 & 0.4 & 8 & 56 & 15 & 1 & 17 & 2 & 1 & 0 & 0 & 0 & 0 & 100.0 \\
\hline Shaybah & 7 & 81 & 14 & 2 & 1 & 1 & 1 & 0 & 0 & 0.2 & 100.0 & .55 & 7 & 1.0 & 6 & 42 & 11 & 1 & 31 & 7 & 0 & 0 & 0 & 1 & 2 & 100.0 \\
\hline Ardah & 9 & 85 & 11 & 3 & 1 & 0 & 0 & 0 & 0 & 0.6 & 100.0 & .48 & 8 & 0.5 & 7 & 40 & 14 & 1 & 25 & 9 & 1 & 0 & 0 & 0 & 2 & 100.0 \\
\hline Oman pediment & 1 & 3 & 0 & 10 & 70 & 13 & 3 & 0 & 0 & 0 & 100.0 & n.d. & & & & & & & & & & & & & & \\
\hline Northwest Oman & 1 & 42 & 15 & 34 & 2 & 1 & 1 & 2 & 1 & 2.2 & 100.0 & .35 & 1 & 2.2 & 6 & 35 & 8 & 0 & 25 & 7 & 12 & 1 & 2 & 1 & 2 & 100.0 \\
\hline Northeast Oman & 1 & 77 & 12 & 8 & 1 & 1 & 0 & 0 & 0 & 0.7 & 100.0 & .19 & 1 & 0.4 & 5 & 34 & 8 & 0 & 28 & 11 & 9 & 0 & 1 & 1 & 0 & 100.0 \\
\hline South Oman & 1 & 96 & 0 & 1 & 0 & 3 & 1 & 0 & 0 & 0.3 & 100.0 & n.d. & 1 & 0.1 & 40 & 1 & 0 & 0 & 10 & 35 & 0 & 0 & 11 & 1 & 2 & 100.0 \\
\hline Sand sheets & 2 & 83 & 9 & 3 & 0 & 0 & 0 & 0 & 1 & 3.1 & 100.0 & .57 & 2 & 3.1 & 4 & 21 & 0 & 0 & 67 & 5 & 1 & 0 & 0 & 0 & 1 & 100.0 \\
\hline SW Rub' al Khali & 12 & 86 & 9 & 1 & 0 & 0 & 1 & 0 & 0 & 1.9 & 100.0 & .52 & 12 & 1.2 & 7 & 31 & 4 & 1 & 52 & 3 & 0 & 0 & 0 & 0 & 2 & 100.0 \\
\hline Ramlat Sab'atayn & 1 & 90 & 3 & 4 & 0 & 1 & 1 & 0 & 0 & 0.6 & 100.0 & n.d. & 1 & 0.5 & 14 & 41 & 12 & 3 & 25 & 3 & 3 & 0 & 0 & 1 & 1 & 100.0 \\
\hline Hadhramaut & 1 & 21 & 0 & 79 & 0 & 0 & 0 & 0 & 0 & 0 & 100.0 & n.d. & & & & & & & & & & & & & & \\
\hline WAJIID SANDSTONE & 1 & 94 & 5 & 0 & 0 & 0 & 0 & 0 & 0 & 0.3 & 100.0 & .63 & 1 & 0.03 & 54 & 9 & 11 & 11 & 9 & 3 & 0 & 0 & 0 & 0 & 3 & 100.0 \\
\hline
\end{tabular}

